Marquette University Law School

Marquette Law Scholarly Commons

Faculty Publications

Faculty Scholarship

$1-1-2008$

\title{
Plea Bargaining and Procedural Justice
}

Michael M. O'Hear

Marquette University Law School, michael.ohear@marquette.edu

Follow this and additional works at: http://scholarship.law.marquette.edu/facpub

3 Part of the Law Commons

Publication Information

Michael M. O’Hear, Plea Bargaining and Procedural Justice, 42 Ga. L. Rev. 407 (2008)

\section{Repository Citation}

O'Hear, Michael M., "Plea Bargaining and Procedural Justice" (2008). Faculty Publications. Paper 557.

http://scholarship.law.marquette.edu/facpub/557

This Article is brought to you for free and open access by the Faculty Scholarship at Marquette Law Scholarly Commons. It has been accepted for inclusion in Faculty Publications by an authorized administrator of Marquette Law Scholarly Commons. For more information, please contact megan.obrien@marquette.edu. 


\title{
PLEA BARGAINING AND PROCEDURAL JUSTICE
}

\author{
Michael M. O'Hear*
}

TABLE OF CONTENTS

I. INTRODUCTION . . . . . . . . . . . . . . . . 409

II. The Practice of Plea Bargaining: ChaRACTERISTICS AND PREMISES . . . . . . . . . . . 414

III. The Case for Procedural Justice . . . . . . . . . . 420

A. INTRODUCTION TO THE SOCIAL PSYCHOLOGY MODEL . . . 420

B. APPLICATION OF THE SOCIAL PSYCHOLOGY MODEL TO PLEA BARGAINING . . . . . . . . . . . . . . . . 424

1. Negotiation Versus Adjudication ...........424

2. Translating Procedural Justice Into Plea Bargaining Process Norms . . . . . . . . 426

3. Salience of Procedural Justice Effects to Criminal Law . . . . . . . . . . . . . . . . . 432

C. DOUBTS ABOUT DISTRIBUTIVE JUSTICE . . . . . . 437

D. COLLATERAL BENEFITS: TRANSPARENCY TO THIRD PARTIES . . . . . . . . . . . . . . . . . . . . 443

* Professor of Law, Marquette University. J.D., B.A., Yale University. Editor, Federal Sentencing Reporter. I am grateful for comments from Rick Bierschbach, Dan Blinka, Josh Bowers, Alafair Burke, Russell Covey, Jason Czarnezki, Margareth Etienne, Rick Garnett, Wayne Logan, Dan Markel, Benji McMurray, Marc Miller, Scott Moss, Chad Oldfather, Mark Osler, Andrea Schneider, Robin Wollford Slocum, Stephanie Stern, Sandra Guerra Thompson, Jenia Iontcheva Turner, David Wexler, Ronald Wright, and participants in a faculty workshop at Chapman University School of Law. I also am grateful for research assistance from Mia Sefarbi and Andrew Hitt. 
IV. RESPONDING TO OBJECTIONS ............. 446

A. OBJECTIONS BASED ON ADVERSE EFFECTS

1. The Transaction Costs of Procedural Justice Will Undermine Efforts to Achieve

Distributively Just Outcomes . . . . . . . . . . 446

a. Voice ....................... 447

b. Objective Criteria, Explanation, and Principled Engagement . . . . . . . . . . . . . 449

c. Avoidance of High-Pressure Tactics . . . . . . . . 453

d. Complementarity of Procedural and

Distributive Justice . . . . . . . . . . . . . . . . 454

2. The Process Is the Punishment: Bringing Procedural Justice to Plea Bargaining Undermines the Invisible Punishment on Which the System Relies . . . . . . . . . . . . . . 455

3. Procedural Justice May Result in Less Favorable Deals for Defendants 457

B. OBJECTIONS BASED ON DOUBTS ABOUT THE BENEFITS OF PROCEDURAL JUSTICE IN PLEA BARGAINING . . . . . . 459

1. The Judge Provides the Procedural Justice . . . . . 459

2. Criminal Defendants Are Different . . . . . . . . . 461

3. Bargaining Is Just a Blip on the Radar Screen . . . 464

4. The Empirical Studies Themselves Indicate a Surprising Degree of Satisfaction with Plea Bargaining . . . . . . . . . . . . . . . . . . . . 465

V. Conclusion $\ldots \ldots \ldots \ldots \ldots \ldots \ldots \ldots \ldots \ldots \ldots 4$ 


\section{INTRODUCTION}

Plea bargaining now dominates the day-to-day operation of the American criminal justice system; about ninety-five percent of convictions are obtained by way of a guilty plea. ${ }^{1}$ Indeed, despite the strenuous objections of prominent academic commentators, ${ }^{2}$ plea bargaining seems to be growing only more entrenched over time. ${ }^{3}$ Increasingly, scholars are turning their attention from abolition to reform, seeking ways to improve an institution that seems unlikely to disappear any time soon. ${ }^{4}$ In particular, recent reform proposals have focused on problems of accuracy and desert, attempting to address concerns that plea bargaining systematically results in

1 See BuReau of Justice Statistics, U.S. Dep'T OF Justice, FeLony Defendants IN LARGE URBAN COUNTIES, 2002, at 28 (2006) ("In felony cases filed in May 2002 in the nation's seventy-five largest counties g]uilty pleas accounted for $95 \%$ of the estimated 31,772 convictions obtained within 1 year of arrest ...."); BUREAU OF JUSTICE STATISTICS, U.S. DEP'T OF JUSTICE, FEDERAL CRIMINAL CASE PROCESSING, 2002, at 11 (2005) [hereinafter FEDERAL Criminal CASE Processing] (showing that in year ending September 30, 2002, 69,072 of total 71,798 federal convictions (or $96.2 \%$ ) were obtained by plea). Overall, taking into account other outcomes besides conviction, about two-thirds of felony cases in state court in large urban counties and about eighty-six percent of all federal criminal cases are resolved by way of a guilty plea. See FELONY DeFENDANTS IN LARGE URBan COUNTIES, supra, at 25 ("[N]early two-thirds of defendants entered a guilty plea at some point . . . ."); FEDERAL Criminal CASe Processing, supra, at 11 (showing that 69,072 out of 80,424 total federal defendants were convicted by way of guilty plea).

${ }_{2}$ See, e.g., Albert W. Alschuler, Implementing the Criminal Defendant's Right to Trial: Alternatives to the Plea Bargaining System, 50 U. CHI. L. REV. 931, 932 (1983) ("Even a cursory listing of objections to this practice may consume several paragraphs."); John $\mathrm{H}$. Langbein, Torture and Plea Bargaining, 46 U. CHI. L. REv. 3, 12-13 (1978) (comparing coercive effects of plea bargaining to medieval torture); Stephen J. Schulhofer, Plea Bargaining As Disaster, 101 YALE L.J. 1979, 1979 (1992) (“[P]lea bargaining seriously impairs the public interest in effective punishment of crime and in accurate separation of the guilty from the innocent.").

${ }^{3}$ See Jacqueline E. Ross, The Entrenched Position of Plea Bargaining in United States Legal Practice, 54 AM. J. COMP. L. 717, 718 (2006) (describing "well-entrenched" position of plea bargaining); Ronald F. Wright, Trial Distortion and the End of Innocence in Federal Criminal Justice, 154 U. PA. L. REV. 79, 91 (2005) (depicting pronounced upward trend in guilty plea rates in federal system since 1981).

${ }_{4}$ See, e.g., Nancy Jean King, Priceless Process: Nonnegotiable Features of Criminal Litigation, 47 UCLAL.REV. 113, 115-17 (1999)(rejecting absolutist positions on negotiability of criminal procedure rights in plea bargaining and proposing "middle ground" inquiry); Gerard E. Lynch, Our Administrative System of Criminal Justice, 66 FoRDHAM L. REV. 2117, 2145 (1998) (characterizing plea bargaining system as "largely acceptable," but not "incapable of improvement"); Fred C. Zacharias, Justice in Plea Bargaining, 39 WM. \& MARY L. REV. 1121, 1123, 1126-27 (1998) ("accept[ing] plea bargaining as a given" and arguing for adoption by prosecutorial offices of clear "plea-bargaining theory"). 
conviction of the innocent, or otherwise imposes punishment that is unjustifiably harsh or lenient. ${ }^{5}$ While such considerations of distributive justice are plainly compelling, this Article argues that procedural justice also ought to be part of the plea bargaining reform agenda. An exclusive focus on the outcomes of plea bargaining misses the important contributions that process potentially makes to the acceptance of outcomes and the perceived legitimacy of the criminal justice system.

What would a procedurally just plea bargaining system look like? In answering this question, I focus particularly on the process by which prosecutors develop, present, and respond to proposed plea agreements, and I draw on a well-established body of social psychology research that has, until recently, largely escaped the attention of criminal law scholars. This research has identified

${ }^{5}$ See, e.g., Oren Bar-Gill \& Oren Gazal Ayal, Plea Bargains Only for the Guilty, 49 J.L. \& ECON. 353, 355-56 (2006) (proposing reforms to reduce risk of convicting innocent); Stephanos Bibas, Plea Bargaining Outside the Shadow of Trial, 117 HARV.L. REV. 2463, 2468 (2004) ("Rather than basing sentences on the need for deterrence, retribution, incapacitation, or rehabilitation, plea bargaining effectively bases sentences in part on wealth, sex, age, education, intelligence, and confidence."); Joseph A. Colquitt, Ad Hoc Plea Bargaining, 75 TUL. L. REV. 695, 759 (2001) (arguing that "ad hoc" plea bargains should be regulated because, inter alia, they "may bear little or no relationship to the charged offense or penological goals"); Markus Dirk Dubber, American Plea Bargains, German Lay Judges, and the Crisis of Criminal Procedure, 49 STAN. L. REv. 547, 600 (1997) (arguing for full implementation of Federal Rule of Criminal Procedure 11 and American Bar Association Standards for Criminal Justice in order to prevent wrongful convictions in plea bargaining); Oren Gazal-Ayal, Partial Ban on Plea Bargains, 27 CARDOZo L. REV. 2295, 2299 (2006) (arguing for partial ban on plea bargaining in order to reduce risk of wrongful convictions); Nancy J. King, Judicial Oversight of Negotiated Sentences in a World of Bargained Punishment, 58 STAN. L. REV. 293, 308 (2005) ("Oversight of negotiated sentences by judges provides some assurance that bargains do not deviate too far, or too often, from legislated limits on punishment."); Susan R. Klein, Enhancing the Judicial Role in Criminal Plea and Sentence Bargaining, 84 TEX. L. REv. 2023, 2028 (2006) ("To ensure accuracy and equality lin plea negotiationsl, federal criminal defendants and jurists need the information necessary to determine whether a prosecutor could prove guilt beyond a reasonable doubt to a jury, and the data regarding charges imposed and sentences levied against suspects alleged to have engaged in similar conduct."); Michael M. O'Hear, The End of Bordenkircher: Extending the Logic of Apprendi to Plea Bargaining, 84 WASH. U. L. REV. 835, 880 (2006) (arguing that coercive force of charging threats increases risk of wrongful convictions); Uzi Segal \& Alex Stein, Ambiguity Aversion and the Criminal Process, 81 NOTRE DAME L. REv. 1495, 1549 (2006) (arguing for giving defendants right to bench trial to "divest the prosecution of its power to force defendants into harsh and inefficient plea bargains"); Jenia Iontcheva Turner, Judicial Participation in Plea Negotiations: A Comparative View, 54 AM. J. COMP. L. 199, 200 (2006) (arguing that greater judicial involvement in plea bargaining "can render the final disposition more accurate"); Wright, supra note 3, at 86 (arguing for sentencing reforms that would improve accuracy of plea bargaining system). 
several factors that contribute to perceptions of procedural justice, including whether the people involved have opportunities to tell their sides of the story (that is, whether they have "voice"), whether the authorities act in a manner that indicates neutrality and trustworthiness, and whether those involved are treated with dignity and respect. ${ }^{6}$

This Article thus offers a first effort in legal literature to apply the social psychology model of procedural justice to the practice of plea bargaining. Using the model, I contend that plea bargaining should be regarded as procedurally just to the extent that prosecutors give defendants opportunities to tell their sides of the story before making or responding to an offer; explain their bargaining positions by reference to objective, uniformly applied criteria; demonstrate consideration of arguments made by defendants; and avoid the use of charging threats and other highpressure tactics to induce guilty pleas. ${ }^{7}$

In practice, many prosecutors and prosecutorial offices already embrace such procedural norms, ${ }^{8}$ but this by no means occurs on a uniform or systematic basis. ${ }^{9}$ For instance, despite detailed guidance regarding other aspects of plea bargaining, there is no treatment of procedural justice considerations in such authoritative statements of prosecutorial norms as the National District Attorneys' Association's National Prosecution Standards or the

${ }^{6}$ See infra notes $35-42$ and accompanying text.

7 See infra notes $64-85$ and accompanying text.

8 For instance, federal prosecutorial offices tend to employ relatively formal plea bargaining procedures that, consciously or otherwise, often comport fairly well with procedural justice norms. For a recent description of plea bargaining practices in one such United States Attorney's Office, see Mary Patrice Brown \& Stevan E. Bunnell, Negotiating Justice: Prosecutorial Perspectives on Federal Plea Bargaining in the District of Columbia, 43 AM. CRIM. L. REV. 1063, 1065-92 (2006). This is not to say, however, the federal practices are beyond criticism. For instance, the time pressures imposed on some defendants to plead guilty pursuant to federal "fast-track" programs raise substantial procedural justice concerns. See Jane L. McClellan \& Jon M. Sands, Federal Sentencing Guidelines and the Policy Paradox of Early Disposition Programs: A Primer on "Fast-Track" Sentences, 38 ARIZ. ST. L.J. 517, 532 (2006) (discussing fast-track sentencing and problems with plea bargaining); see also Lynch, supra note 4, at 2125 (describing "practices characteristic of federal white-collar criminal investigations involving well-financed defendants" as "somewhat idealized version of the plea bargaining process").

${ }_{9}$ See Lynch, supra note 4, at 2129 (noting that plea bargaining procedures are not codified, "but negotiated case-by-case in the context of customary practice"). 
Department of Justice's United States Attorneys' Manual..$^{10}$ Indeed, such disregard of procedural justice by prosecutors is to be expected: social psychology research indicates that, while decision recipients evaluate fairness based chiefly on process, decision makers focus largely on outcomes. ${ }^{11}$

Though unsurprising, the neglect of procedural justice is unfortunate. The social psychology research indicates that implementing procedural justice norms not only may increase defendant satisfaction with plea-bargained outcomes (even if the outcomes themselves remain substantively unchanged), but also may contribute to the perceived legitimacy of the criminal justice system and ultimately enhance defendants' levels of voluntary compliance with legal rules and authorities. ${ }^{12}$ There are, in short, good reasons to believe that greater attentiveness by prosecutors to procedural justice may increase the cooperativeness of defendants while they are under criminal justice supervision and decrease their likelihood of recidivism. ${ }^{13}$

10 See NAT'L Dist. ATtORnEYs' Ass'N, NATIONAL Prosecution StandaRDS 190-99 (2d ed. 1991) (discussing standards for plea negotiations); U.S. DEP'T OF JUSTICE, UNITED STATES ATTORNEYS'MANUAL \$§ 9-16.001-16.500,9-27.330-27.650(2006) (setting standards for pleas).

11 See Larry Heuer, What's Just About the Criminal Justice System? A Psychological Perspective, 13 J.L. \& POL'Y 209, 214-18 (2005) (reviewing decisionmaker studies).

${ }_{12}$ See generally Jonathan D. Casper et al., Procedural Justice in Felony Cases, 22 LAW \& SOC'Y REV. 483 (1988) (discussing research on determinants of litigant satisfaction, effects on procedural and distributive fairness, and implications for plea bargaining).

${ }_{13}$ See generally Raymond Paternoster et al, Do Fair Procedures Matter? The Effect of Procedural Justice on Spouse Assault, 31 LAW \& SoC'Y REV. 163 (1997) (discussing study in which procedural justice was associated with reduced recidivism). In this Article, I focus on how the prosecutor's conduct during plea negotiations may diminish recidivism risks. Another promising body of literature explores the potential for defense counsel to contribute to rehabilitation in the plea-bargaining setting. See, e.g., David B. Wexler, Therapeutic Jurisprudence and the Rehabilitative Role of the Criminal Defense Lawyer, 17 ST. THOMASL. REV. 743, 753-55 (2005) (discussing potential for empathy training for defense clients); Bruce J. Winick, Redefining the Role of the Criminal Defense Lawyer at Plea Bargaining and Sentencing: A Therapeutic Jurisprudence/Preventive Law Model, 5 PSYCHOL. PUB. POL'Y \& L. 1034, 1049-51 (1999) (discussing, inter alia, defense lawyers' assistance with post-offense rehabilitation and use of rehabilitative efforts to negotiate downward departures in sentencing ranges). For a skeptical view of this literature, see Mae C. Quinn, An RSVP to Professor Wexler's Warm Therapeutic Jurisprudence Invitation to the Criminal Defense Bar: Unable to Join You, Already (Somewhat Similarly) Engaged, 48 B.C. L. REV. 539, 541 (2007) ("[Professor David Wexler's] model not only runs the risk of displacing existing defense and clinical community values, but may well conflict with ethical and legal mandates for defense attorneys."). 
I thus propose a novel criterion by which to evaluate ploa bargaining practices, that is, whether defendants perceive the practices to be procedurally just. This criterion supports the implementation of reforms that are both practically feasible and capable of making important contributions to the ability of the criminal justice system to deliver efficient crime control.

To be clear, I do not claim here that the proposed procedural justice norms are constitutionally or statutorily mandated (although I have argued elsewhere that charging threats do indeed raise serious constitutional problems ${ }^{14}$ ). Nor do I claim that these norms must always trump other objectives of the criminal justice system (such as speedy case processing) when and if they conflict. Rather, the point is that prosecutors should more systematically attend to procedural justice in plea bargaining; incorporate procedural justice into influential statements of prosecutorial norms, such as the National Prosecution Standards; and consider specific changes in office policies and practices that would bring plea bargaining into greater conformity with the procedural justice model. ${ }^{15}$

The Article proceeds in three parts, as follows. Part II sets forth background on plea bargaining. Part III lays out the basic case for procedural justice in plea bargaining. I summarize the pertinent social psychology research and theorizing, discuss how this work might apply in the plea bargaining context, and argue that the effects associated with procedural justice - greater acceptance of adverse decisions, enhanced perceptions of legitimacy, and higher levels of voluntary compliance with the law and legal authorities-are important and legitimate objectives of the criminal justice system. Finally, Part IV addresses a variety of potential objections, including, perhaps most importantly, those arising from

14 See O'Hear, supra note 5, at 840 (proposing "a new rule of constitutional law that the [Supreme Court] should adopt if given a fresh opportunity to address the issue of prosecutorial charging threats").

15 As Ronald Wright and Marc Miller have recently observed, the internal administration of "justice agencies," such as prosecutorial offices, largely has been neglected by legal scholars. Ronald Wright \& Marc Miller, The Screening/Bargaining Tradeoff, 55 STAN. L. REV. 29, 55 (2002). This is an unfortunate tendency, as they observe, because "scholars overlook central features of the American criminal justice system when they fail to consider the values that agencies might seek and how they might achieve those goals through internal rules." Id. Consonant with Wright and Miller's project, this Article might be thought of as an effort "to consider the values [i.e., procedural justicel that agencies might seek." Id. 
the transaction costs of procedural justice. These objections underscore the need for further empirical research and experimentation, but they are not so compelling on their face as to justify the continuing neglect of procedural justice by plea bargaining scholars and practitioners.

\section{The Practice of Plea Bargatning: CharaCteristics AND PREMISES}

This Part offers a brief overview of plea bargaining, suggesting along the way circumstances that are particularly likely to give rise to procedural justice problems. In developing a workable model of plea bargaining, the diversity of the real world must be reduced to manageable proportions. Thus, for simplicity's sake, I assume that plea bargaining is a bilateral interaction between a prosecutor on one side, and a defendant and his or her lawyer on the other, thereby disregarding the important role that judges sometimes play as de facto bargainers. ${ }^{16}$ I also assume that negotiations involve a lawyer on the defense side, thus leaving to one side those cases in which prosecutors negotiate directly with defendants themselves. ${ }^{17}$ Finally, I assume that a plea offer (which can be made by either side) involves an express promise by the defendant to plead guilty to one or more specified charges in return for either the dismissal of other charges, a favorable sentencing recommendation by the prosecutor or both. ${ }^{18}$

${ }^{16}$ See Seung-Hee Lee, The Scales of Justice: Balancing Neutrality and Efficiency in PleaBargaining Encounters, 16 DISCOURSE \& SOC'Y 33, 34 (2005) (summarizing normative and empirical literature on judge's role in plea bargaining). Note, however, that in the federal system, as well as some state systems, judges are prohibited or discouraged from participating in plea negotiations. See Turner, supra note 5, at 202 ("Under Federal Rule 11, judges may not take any part in plea negotiations or even make comments that might indirectly influence the bargaining process.").

17 This direct negotiation phenomenon is particularly important in less serious cases, in which there may be no constitutional right to appointed counsel for indigent defendants. See Scott v. Illinois, 440 U.S. 367, 373 (1979) (holding there is no right to appointed counsel in cases in which fine, but not imprisonment, is imposed). Even where the constitutional right to appointed legal counsel exists, however, it is common in some jurisdictions for defendants to waive the right and negotiate directly with prosecutors. See Mary Sue Backus \& Paul Marcus, The Right to Counsel in Criminal Cases, A National Crisis, 57 HaSTINGs L.J. 1031, 1077-78 (2005) (describing Georgia courts in which, after meeting with prosecutor, "every defendant informs the judge that he would like to waive counsel and plead guilty").

18 I thus exclude consideration of the phenomenon that some scholars label "implicit plea 
Field studies of plea bargaining draw an important distinction between routine case processing and more adversarial interactions. ${ }^{19}$ In routine case processing, cases are resolved quickly, with little or no haggling, shortly before or during a routine, preliminary court appearance by the defendant, such as arraignment. ${ }^{20}$ Consider, for instance, Milton Heumann's description of practices in Connecticut state court:

Typically, in the circuit court, a line forms outside the prosecutor's office the morning before court is convened. Defense attorneys shuffle into the prosecutor's office and, in a matter of two or three minutes, dispose of the one or more cases "set down" that day. Generally, only a few words have to be exchanged before agreement is reached. The defense attorney mutters something about the defendant, the prosecutor reads the police report,

bargaining." See CANDACE MCCOY, POLITICS AND PleA BARGaINING: VICTIMS' RightS IN CALIFORNIA 52 (1993) ("An implicit plea 'bargain' occurs when a defendant pleads guilty after conferring with the defense attorney about the probability of achieving a particular sentence, considering the judge's record and temperament. The defendant confesses and expects to receive the sentence the judge usually imposes for that type of crime.").

19 See, e.g., Douglas W. Maynard, Inside Plea Bargaining: The Language of NEGOTIATION 103-18 (1984) (discussing routine and adversarial justice). Unfortunately, most of the leading academic field studies of plea bargaining were conducted twenty to forty years ago. For examples of these studies, see generally JAMES EISENSTEIN ET AL., THE CONTOURS OF JUSTICE: CoMmUNITIES AND THEIR COURTS (1988); MALCOLM M. FEELEY, THE PROCESS IS THE PUNISHMENT: HANDLING CASES IN A Lower CRIminal Court (1979); Milton HeumanN, Plea Bargaining: The ExPERIENCES of Prosecutors, JUDGES, and DEFENSE ATtorneys (1978); and MAYNARD, supra. However, some key observations of the earlier research (e.g., the notion of a "going rate" for different offense types and a focus on case categorization during "negotiations") also are consistent with the findings of more recent research in other jurisdictions. See, e.g., MCCOY, supra note 18, at 130-32 (recognizing going rate of punishment); Deirdre M. Bowen, An Analysis of Alternative Methods of Plea Bargaining 188 (2002) (unpublished Ph.D. dissertation, University of Washington) (on file with author) (discussing norms and principles used to arrive at plea bargain); Stacey Thompson Hephner, Negotiation: The Strength of the Courtroom Workgroup and the Guilty Plea Process 70 (2002) (unpublished Ph.D. dissertation, Sam Houston State University) (on file with author) (discussing use of "going rates for an offense" and effect on sentencing practices). While plea bargaining has undoubtedly been affected by such developments as the widespread adoption of sentencing guidelines and mandatory minimums in the $1980 \mathrm{~s}$ and $1990 \mathrm{~s}$, the classic field studies remain useful and well regarded repositories of insight. See, e.g., William J. Stuntz, Plea Bargaining and Criminal Law's Disappearing Shadow, 117 HARV. L. REV. 2548, 2561 (2003) (characterizing Heumann's study of plea bargaining in Connecticut in 1970s as "still the best account of the practice").

20 See HeUmanN, supra note 19 , at 35 (describing routine of some courts). 
and concurrence on "what to do" generally, but not always, emerges. ${ }^{21}$

As Malcolm Feeley memorably put it, plea bargaining in this mode resembles less a Middle Eastern bazaar than shopping in a supermarket:

Arriving at an exchange in this context is not an explicit negotiation and bargaining process .... To the extent that there is any negotiation at all, it is debate over the nature of the case, and hinges largely on establishing the relevant "facts" which flow from various interpretations of the police report, and only occasionally involve independent investigation by a defense. In a supermarket customers may complain about prices, but rarely "bargain" to get them reduced. ${ }^{22}$

This mode of plea bargaining is most closely associated with highvolume, low-stakes cases like misdemeanors and low-grade felonies, as well as cases in which the prosecutor and defense lawyer have a good relationship and a long history of past dealings. ${ }^{23}$

Many defendants welcome the impersonal, rapid-fire nature of the routine case processing mode, preferring just to "get it over with" in cases that are unlikely to result in substantial sentences of incarceration. ${ }^{24}$ From a procedural justice standpoint, though, the concern is that not all defendants are content with letting the police report do the talking for them.

Even if the report is entirely accurate, the defendant may have a "story" to tell that would contextualize the information collected by the police. And even if that context is irrelevant to the lawyers' assessment of the case, it may nonetheless be subjectively important to the defendant to tell his or her side of the story. Yet, in the routine case processing mode, the defendant may have no opportunity to do so until after the prosecutor has decided what the

2i Id. at 35 (footnotes omitted).

22 FEELEY, supra note 19 , at 187-88.

23 See Brown \& Bunnell, supra note 8, at 1065-66 (discussing conditions permitting quick and efficient plea negotiations in federal cases).

24 FEELEY, supra note 19 , at 30-31. 
plea offer will be (if even then). Given the realities of criminal defense-notoriously overburdened public defenders, as well as private defense lawyers whose practice economics also demand speedy case processing-the defendant's lawyer will rarely spend much time with the defendant before an agreement is reached with the prosecutor. ${ }^{25}$ At that point, the pressure will be on the defendant simply to consent to the deal without troubling anyone with new information. ${ }^{26}$ In such a case, the defendant would be well justified in concluding that he or she has no real voice in the process.

The adversarial mode of plea bargaining raises different concerns. In this mode, there is some obstacle to resolving the case quickly by reference to shared understandings as to the "worth" of various generic case types. ${ }^{27}$ When this occurs, the prosecutor may assume one or more of a variety of different postures. For instance, the prosecutor may adopt a position of principled engagement, substantively addressing the defendant's views of the case, either accepting the defendant's basic framework for evaluating the case or explaining why that framework is not the appropriate one. ${ }^{28} \mathrm{Or}$

25 See, e.g., STEve Bogira, CoURTroom 302: A YeAR BEHIND the SCENES IN AN AMERICAN CRIMINAL COURTHOUSE 124 (2005) (describing public defenders' reliance on police reports in evaluating cases); Backus \& Marcus, supra note 17, at 1033, 1053-57 (describing caseload pressures on public defenders). For a classic treatment of the economic pressures that induce private counsel to seek quick pleas, see Albert W. Alschuler, The Defense Attorney's Role in Plea Bargaining, 84 YALE L.J. 1179, 1182-83, 1198-1203 (1975). Court-appointed attorneys may face similar pressures unless they are compensated on an hourly basis. See Alschuler, supra, at 1262-63 ("The most satisfactory technique for compensating an appointed attorney is probably to pay an established hourly rate."). "Twenty-five or $\mathbf{5 0}$ dollars may seem seriously inadequate as compensation for defending a person at trial, but some lawyers view it as a generous enough reward for conferring with a client for 10 minutes and then standing with him in the courtroom to enter a plea of guilty." Id. at 1262.

${ }_{26}$ See, e.g., BOGIRA, supra note 25, at 118 ("Some [public defenders in Chicago] said they felt pressured to advise their clients to decide in five minutes whether to plead guilty or not.").

${ }_{27}$ To note just a few potential obstacles, the case may be a manifestly unusual one with no clear going rate, there may be a genuine factual disagreement as to what type of case it is, or one of the negotiating parties may be a neophyte with unrealistic expectations.

${ }^{28}$ For an example of principled engagement in one courthouse see Douglas Maynard's study of plea bargaining in MAYNARD, supra note 19, at 108. The prosecutor in a DUI case offered a reduced fine if the defendant pled guilty. Id. In arguing for an even more lenient deal, the defendant's lawyer asserted that "[the defendant is] basically not a drinker, um might have a couple of beers once in a while, but she's not really a-she doesn't really drink." Id. In response, the prosecutor disputed the factual assertion that the defendant was not a "drinker," but implicitly accepted the premise that the defendant's alcohol consumption habits were relevant to disposition of the case. See id. (saying "somebody who's not a drinker doesn't 
the prosecutor may assume a posture of unprincipled acquiescence, that is, simple "horse trading," for instance, if a prosecutor responds to a defendant's argument for lenience by offering a sentence recommendation exactly half-way between the original offer and the counter-offer. Alternatively, the prosecutor may respond to resistance by withdrawal from negotiations or by threatening to penalize the defendant for his or her failure to take the proffered deal. ${ }^{29}$

From a procedural justice standpoint, the chief concern in the adversarial setting is not so much one of voice, ${ }^{30}$ but rather that, outside the principled engagement scenario, the prosecutor effectively is saying that the defendant's view of the case does not matter; the defendant's perspective is not only wrong, it is not even worthy of substantive response. Although the defendant nominally has a voice opportunity, that opportunity may seem something of a sham.

It is important to recognize that in the end, regardless of the prosecutor's stance in any given case, there will almost certainly be a guilty plea. ${ }^{31}$ Prosecutors can act in a high-handed way because few defendants can afford to go to trial. The costs of trial extend far beyond the litigation expenses (from which low-income defendants are generally insulated anyway). For those who cannot make bail, the unpleasantness of pretrial detention may be a very effective

just go to a liquor store and buy uh pre-made uh cocktails. I think that she is a drinker."). Alternatively, the prosecutor's response might be characterized as "engaged." The prosecutor could have expressly rejected the defense lawyer's premise on principled grounds and said, for instance, "I understand your contention that your client is not a drinker, but that is not an element of the offense, and I believe that it is important to ensure there are substantial penalties in all DUI cases in order to send a consistent deterrent message."

${ }_{29}$ For instance, in Bordenkircher v. Hayes, 434 U.S. 357, 358 (1978), which began as a routine bad check case, the prosecutor threatened, and ultimately brought, habitual offender charges against the defendant in retaliation for the defendant's refusal to accept the prosecutor's initial plea offer.

${ }^{30}$ I say this because there is not likely to be a real dispute unless the defendant is offering a view of the case that is at odds with the prosecutor's. There may be voice issues, though, if the dispute arises from the views of the defendant's lawyer, and not the defendant himself or herself. For instance, such issues may arise if the lawyer is pushing a suppression issue that is not of genuine concern to the client, while wholly disregarding the client's legally dubious, but keenly felt, entrapment claim.

${ }^{31}$ See BUREAU OF JUSTICE STATISTICS, U.S. DEP'T OF JUSTICE, SOURCEBOOK OF CRIMINAL JUSTICE STATISTICS ONLINE tbl. 5.17.2004, http://www .albany.edu/sourcebook/pdf/t5172004. pdf (showing in fiscal year 2004, of 83,391 criminal defendants in federal district court, 72,152 pled guilty or nolo contendere). 
deterrent to trial..$^{32}$ For those who secure pretrial release, there will be a desire to draw tedious, inconvenient, and sometimes humiliating court appearances to an end. Perhaps most importantly, though, it is well recognized that judges routinely impose substantial penalties at sentencing on those defendants with the temerity to go to trial, sometimes doubling the punishment, or worse. $^{33}$ Thus, many defendants will perceive no realistic alternative to whatever the prosecutor offers.

In any event, we have now preliminarily identified two areas of procedural justice concern: the defendant who is railroaded into accepting a deal without first having a meaningful opportunity to tell his or her side of the story, and the defendant who faces a high-

32 See David Heilbroner, Rough JUSTICE: Days AND NightS OF A Young D.A. 47 (1990) (describing judge's use of pointed reminder of potential length of pretrial detention as means of inducing defendants to accept plea offers); Bibas, supra note 5, at 2491-93 (noting that in misdemeanor and lesser felony cases, many more defendants are held in pretrial custody than are sentenced to incarceration after conviction).

${ }^{33}$ It is difficult to quantify the "trial penalty" with precision because of the possibility that the characteristics of cases going to trial differ in important ways from those of cases being resolved by guilty plea. However, several studies that attempt like-to-like comparisons do find quite substantial differences in the sentences imposed after jury trials relative to those imposed after guilty pleas. For instance, in one study of sentences imposed for different offense types in five states, researchers found "consistent support" for the hypothesis that jury trial cases are associated with harsher average sentences than guilty plea cases, including a finding of a $350 \%$ plea-trial differential in sentence length in heroin distribution cases in one state. Nancy J. King et al., When Process Affects Punishment: Differences in Sentences After Guilty Plea, Bench Trial, and Jury Trial in Five Guidelines States, 105 ColuM. L. REV. 959, 973, 975 (2005). In another empirical study of 2,772 cases that resulted in prison terms, researchers found that sentences following jury trials were 44.5 months longer than those following guilty pleas, after controlling for offense type, criminal justice status at time of arrest, prior record, attorney type, geographic location, pretrial status, age, race, and gender. See Candace McCoy, Plea Bargaining As Coercion: The Trial Penalty and Plea Bargaining Reform, 50 CRIM. L.Q. 67, 88-90 (2005) (describing comparison of "similar cases"); see also Jeffery T. Ulmer \& Mindy S. Bradley, Variations in Trial Penalties Among Serious Violent Offenders, 44 CRIMINOLOGY 631, 650, 652 (2006) (using Pennsylvania data, finding that defendants convicted after jury trial were about 2.7 times more likely to be incarcerated than those convicted after guilty plea, and received sentences fifty-seven percent longer). While most empirical studies have found a trial penalty, not all have, which may reflect differences in jurisdictions and offense types studied, as well as different definitions of what would constitute a trial penalty. For a recent summary of the empirical literature, see Ulmer \& Bradley, supra, at 632-33. In the federal system, the trial penalty has been formalized in the sentencing guidelines, which provide a twenty-five to thirty-five percent "discount" for defendants who plead guilty. Bibas, supra note 5, at 2489. Of course, as Candace McCoy has observed, "The critical point is that almost everyone, including defendants, believe[s] that [the trial penalty exists]." MCCOY, supra note 18, at 164. It is this belief that, whether or not empirically verifiable, drives the perceived need to plead guilty. Id. 
handed prosecutor unwilling to address his or her view of the case in a principled fashion. The next Part will explain in more rigorous fashion why these scenarios should be avoided - even assuming that they do not result in distributively unjust outcomes.

\section{The CASE For PRocedural JUStice}

This Part makes the basic case for attending to procedural justice in plea bargaining. I rely primarily on the empirical research and theorizing of social psychologist Tom Tyler and his collaborators, whose work on procedural justice over more than two decades has proven immensely influential in the social sciences. ${ }^{34}$ After a brief introduction to Tyler's procedural justice model, I consider how it might be translated into the plea bargaining context. Next, I discuss difficulties with the pursuit of distributive justice in plea bargaining. As we will see, the uncertainty surrounding distributive justice in this setting increases the salience of procedural justice. Finally, I consider an important collateral benefit of procedural justice: enhanced transparency for system outsiders-victims and the public at large.

\section{A. INTRODUCTION TO THE SOCIAL PSYCHOLOGY MODEL}

Tyler's model rests on three interrelated claims. First, a person's perception of whether a decisionmaking process was fair does not depend solely on the outcome, but also on various attributes of the process used to reach the outcome. ${ }^{35}$ Those attributes include: (1)

34 See, e.g., RICHARD SPARKS ET AL., PRISONS AND THE PROBlem OF ORDER 87 (1996) (characterizing Tyler's work as "important" and "persuasive[ ]"); Heuer, supra note 11, at 210 (stating Tom Tyler and E. Allan Lind's group value theory represents "the most influential answer to [the] question" of why opportunity for voice in decisionmaking increases perceptions of procedural fairness and satisfaction); Erik Luna, Principled Enforcement of Penal Codes, 4 Buff. CRIM. L. REv. 515, 575 (2000) ("The most extensive work in this area has been done by social psychologist Tom Tyler."); Robert J. MacCoun, Voice, Control, and Belonging: The Double-Edged Sword of Procedural Fairness, 1 ANN. REv. L. \& Soc. SCI. 171, 172 (2005) ("The second decade of procedural justice research centered on the remarkably prolific solo and joint efforts of Tom Tyler and Allan Lind . . ..").

${ }_{35}$ See TOM R. Tyler \& Yuen J. HuO, TRUST in THE LaW: EnCOURAging Public COOPERATION WITH THE POLICE AND COURTS 196 (2002) (“P]eople's main consideration when evaluating the police and the courts is the treatment that they feel people receive from those authorities."); Tom R. Tyler, Procedural Justice, Legitimacy, and the Effective Rule of Law, 30 
whether the person had an opportunity to tell his or her side of the story ("voice"); (2) whether the authorities were seen as unbiased, honest, and principled ("neutrality"); (3) whether the authorities were seen as benevolent and caring ("trustworthiness"); and (4) whether the person was treated with dignity and respect. ${ }^{36}$ The perception of voice, neutrality, trustworthiness, and respect can promote the acceptance of decisions that are otherwise believed to be incorrect or substantively unfair. ${ }^{37}$ Indeed, in many settings, perceptions of process fairness exert greater influence over acceptance of the result than do the outcomes themselves. ${ }^{38}$ Second, the extent to which decisionmaking processes are perceived as fair helps shape beliefs regarding the legitimacy of the legal authorities responsible for the decision. ${ }^{39}$ And third, the perception that legal authorities have legitimacy enhances the sense that the authorities are entitled to be obeyed. ${ }^{40}$ Fair procedures thus promote

CRIME \& JUST. 283, 286 (2003) ("[I] ssues of process dominate public evaluations of the police, the courts, and social regulatory activities.").

${ }^{36}$ Tom R. Tyler \& Hulda Thorisdottir, A Psychological Perspective on Compensation for Harm: Examining the September 11th Victim Compensation Fund, 53 DEPAUL L. REV, 355, 380 (2003).

${ }^{37}$ Tom R. Tyler \& E. Allen Lind, Procedural Justice, in HANDBOOK OF JUSTICE RESEARCH IN LAW 65, 65 (Joseph Sanders \& V. Lee Hamilton eds., 2001).

${ }^{38} I d$. at 71. Tyler sometimes uses different terms than those employed in this four-factor framework. For instance, Tyler and Huo describe acceptance of decisions made by legal authorities as a function of two variables: "procedural justice" and "motive-based trust." TYLER \& HUO, supra note 35, at 76. These two variables, however, are implicit in the four factors noted in the text. "Motive-based trust" corresponds to trustworthiness. Compare id. at 80 (measuring motive-based trust by reference to questions "Did the authority try to be fair to you?" and "Did the authority consider your in put in making decisions?"), with Tom R. Tyler, The Psychological Consequences of Judicial Procedures: Implications for Civil Commitment Hearings, 46 SMU L. REV. 433, 441 (1992) (defining perceived trustworthiness by reference to whether authorities "want to treat [people with whom they are dealing] fairly" and identifying consideration of arguments as important component of this judgment). Meanwhile, Tyler and Huo's notion of procedural justice encompasses voice, neutrality, and respect. See TYLER \& HUO, supra note 35, at 80 (identifying questions used to assess procedural justice in study). In other words, in some studies, Tyler treats trustworthiness as a component of procedural justice, see, e.g., Tyler \& Thorisdottir, supra note 36 , at 380 (identifying trustworthiness as component of procedural justice), while in others he treats procedural justice and trustworthiness as distinct concepts, see, e.g., TYLER \& HUO, supra note 35 , at 76 (treating trustworthiness separately). Because both phenomena are found to contribute to the legitimacy and acceptance effects that are of present concern, TYLER \& HUO, supra note 35, at 76, I group them together in this Article under the single heading of "procedural justice" as a convenient shorthand.

99 Tyler, supra note 35 , at 286.

$40 I d$. 
cooperation with the authorities and compliance with their directives, as well as the development of a more general sense of obligation to obey the law. ${ }^{41}$

These three claims are backed, to a greater or lesser extent, by three decades of social psychology research, encompassing both laboratory and field studies. ${ }^{42}$ The studies are too numerous to summarize (or even cite) here ${ }^{43}$ but a brief description of two especially relevant studies will illustrate the nature of the available empirical support. In one, Jonathan Casper and his colleagues interviewed 628 felony defendants in three cities. ${ }^{44}$ They found that procedural justice in the processing of the defendants' cases made a significant contribution to outcome satisfaction. ${ }^{45}$ They further found a significant correlation between defendants' perceptions of procedural justice and the amount of time they spent speaking with their lawyers (which they associated with voice) and the respectfulness of the treatment they received from police officers at the time of arrest. ${ }^{46}$ In a second criminal justice study, Raymond Paternoster and his colleagues gathered information regarding 479 domestic violence arrestees. ${ }^{47}$ They determined that "[w]hen police acted in a procedurally fair manner when arresting assault suspects, the rate of subsequent domestic violence was significantly lower than when they did not." ${ }^{\text {"48 }}$ They measured procedural justice by reference to such variables as whether officers "took the time" to listen to the arrestee's side of the story and whether the arrestee was handcuffed in front of the victim (which they related to respectful treatment). ${ }^{49}$

41 Id. at 297.

42 See Tyler \& Lind, supra note 37, at 70-71 (discussing research and studies).

43 See MacCoun, supra note 34, at 172 ("As of early 2005, the PsychInfo database list[ed] almost 700 articles with the phrase 'procedural justice' in the abstract (more than 40 per year since 1995 and more than 70 per year in 2000-2003) . ... ). As Robert MacCoun observes: "Few if any socio-legal topics ... have received as much attention using as many different research methods." Id. at 173. For a recent summary of the literature, see $i d$. at 174-88.

44 Casper et al., supra note 12 , at $487-88$.

45 Id. at 494.

46 Id at 498 .

47 Paternoster et al., supra note 13, at 175-76.

48 Id. at 163.

49 Id. at 177-78. These studies, representative of much of the procedural justice research, are admittedly not without their limitations. They are, for instance, correlational studies that, despite sophisticated statistical analysis, leave uncertainty as to the key 
Despite the strong empirical evidence supporting Tyler's model, there is less certainty as to the underlying psychological mechanisms. Tyler himself emphasizes two overlapping mechanisms. First, because "people derive much of their social identity from their standing as full-fledged members of their group or society," fair procedures matter to the extent that they communicate positive messages as to social standing. ${ }^{50}$ Second,

questions of causation. See MacCoun, supra note 34, at 173-74 (discussing uncertainty about causation that exists in field studies). Another difficulty with many studies lies in the subjectivity and potential untrustworthiness of self-reported attitudes about procedural justice. See Paul G. Chevigny, Fairness and Participation, 64 N.Y.U. L. REv. 1211, 1212 (1989) ("IS]ubjects who seem to prefer neutral procedures may be expressing political pieties to which they think it would be best to appear to subscribe."). It is important to realize, though, that procedural justice effects have been identified in a great number of studies conducted with diverse methodologies. As Robert MacCoun observed in a recent review of the literature, "[T]he sheer heterogeneity of tasks, domains, populations, designs, and analytic methods provides remarkable convergence and triangulation." MacCoun, supra note 34, at 173. He concluded that "most concerns about the external validity of the fair process effect (and its antecedents and consequences) have long since been settled." Id.; see also id. at 181 ("There is ample evidence that procedural fairness and legitimacy are correlated, and it is almost surely the case that the correlation reflects causation in both directions."). Even critics of Tyler have conceded that the evidence in support of key components of his model is "persuasive." Chevigny, supra, at 1217.

Objections to the Tyler model center not on its descriptive accuracy, but rather on the possibility that it may be manipulated by authorities to create a "false consciousness," i.e., a sense of satisfaction with outcomes that are distributively unjust. See, e.g., MacCoun, supra note 34, at 188 ("For many scholars, fair process effects are so robust that they raise the specter of 'false consciousness'- the Marxist notion that political and market institutions keep the proletariat ignorant of capitalism's true nature."); Austin Sarat, Authority, Anxiety, and Procedural Justice: Moving from Scientific Detachment to Critical Engagement, 27 LAW \& SOC’Y REV. 647, 658 (1993) (reviewing TOM R. TYLER, WHY PEOPLE OBEY THE LAW (1990)) ("I am concerned that behind the thin veil of Tyler's self-proclaimed neutrality is an alliance between the study of procedural justice and the project of legitimation itself, between the study of why people obey and the effort to provide greater space for the exercise of legal power."). The critique is an important one, yet, given the dynamic and uncertain nature of what people "really" want by way of outcomes, difficult to assess. See MacCoun, supra note 34, at 191 (noting that determining what citizens want from procedure "turns out to be surprisingly tricky"). Tyler has acknowledged, but generally sidestepped, the problem. See, e.g., Tyler, supra note 35 , at 285 ("[T]he model does not address normative issues concerning whether people ought to defer to legal authorities and generally obey the law.... If the social structure is viewed as fundamentally unfair by particular people or groups, then their willingness to comply might be regarded as 'false consciousness' - that is, as a willingness that should be discouraged. These issues are not addressed here." (citations omitted)). For present purposes, I simply will assume that the mandates of the criminal law and criminal justice authorities generally ought to be respected and obeyed.

50 See Tyler \& Lind, supra note 37 , at 76 ("When one is treated politely and with dignity and when respect is shown for one's rights and opinions, feelings of positive standing are enhanced. On the other hand, undignified, disrespectful, or impolite treatment by an 
there is a natural relationship between procedural fairness and expectations of fair outcomes over the long run. If, in an initial transaction with legal authorities, a person perceives the authorities as procedurally fair, then that person is apt to form a judgment that the authorities generally act in a fair manner-a judgment that might be referred to as a "fairness heuristic." ${ }^{\text {"1 }}$ Even if the outcome in the initial transaction was unfavorable, the expectation that fair procedures will be used in the future lends reassurance that subsequent transactions are likely to produce fair outcomes, promoting a greater sense of security about "the long-term gains from group membership," one's resources and identity in an ordered society. ${ }^{, 53}$

B. APPLICATION OF THE SOCIAL PSYCHOLOGY MODEL TO PLEA BARGAINING

1. Negotiation Versus Adjudication. At first blush, plea bargaining may not seem a good fit with Tyler's model. After all, much of the social psychology research focuses on unilateral decisions of legal authorities, such as decisions by police officers to make an arrest or formal court-based adjudications. ${ }^{54}$ "Bargaining" would seem a very different way of reaching a decision, one in which the freedom of each party to veto any proposed agreement might plausibly obviate the need for, say, symbolic affirmations of social status-respect for individual autonomy would seem intrinsic to the transaction. Indeed, influential early research on procedural justice suggested that people in disputes place a high value on retaining direct control over decisions, indicating that negotiated resolutions

authority carries the implications that one is not a full member of the group." (citations omitted)).

${ }^{51}$ Id. at 76-77. This concept is particularly associated with Tyler's frequent collaborator E. Allan Lind. For a more extensive discussion by Lind of the fairness heuristic, see E. Allan Lind, Procedural Justice, Disputing, and Reactions to Legal Authorities, in EVERYDAY Practices AND Trouble CASES 177, 185-88 (Austin Sarat et al. eds., 1998).

52 Tyler \& Lind, supra note 37 , at 76.

53 Id. at 77.

54 See Nancy A. Welsh, Perceptions of Fairness in Negotiation, 87 MARQ. L. REv. 753, 764 (2004) ("Most of the research that has been done regarding procedural justice has focused on people's interactions with third-party authorities in dispute resolution or decision making processes (e.g., judges, arbitrators, managers, mediators)."). 
would generally be preferred on process grounds to adjudication. ${ }^{55}$ This view, how ever, proved inconsistent with subsequent empirical work, ${ }^{56}$ which instead has tended to emphasize voice and other aspects of Tyler's procedural justice model over decision-control per se. ${ }^{57}$ Indeed, a growing body of work tends to find much the same procedural justice dynamic at work in negotiation as in adjudication. ${ }^{58}$ Even in a relatively high decision-control scenario, people still value respectful treatment and a meaningful opportunity to tell their side of the story.

Moreover, it is easy to overstate the extent to which plea bargaining really is bargaining. ${ }^{59}$ As noted previously, the practice often resembles shopping in a supermarket ${ }^{60}$ - with one important exception: the dissatisfied defendant is not free to move on to a different store in search of lower prices. Even when plea bargaining takes on a more adversarial character, there tends to be massive power imbalances between prosecutors and defendants. In light of such considerations as transaction costs and judicially imposed trial penalties, few defendants are willing to go to trial. ${ }^{61}$ Furthermore, the proliferation of sentencing guidelines and mandatory minimum sentences over the past quarter-century has given prosecutors even greater leverage over defendants than they have traditionally enjoyed; when prosecutorial lenience is the only reliable means to avoid a draconian sentence, the prosecutor can effectively dictate the terms of the "deal." Bargaining dynamics vary considerably

${ }^{55}$ See Tyler \& Lind, supra note 37, at 74-75 (discussing theory of Thibaut and Walker that "disputants define procedural justice in control terms").

56 Id. at 75.

57 Welsh, supra note 54 , at 764 .

${ }^{58} I d$.

59 See Lynch, supra note 4, at 2129 ('[T]he very term 'plea bargaining' is something of a misnomer.").

60 See supra note 22 and accompanying text.

61 See supra notes 32-33 and accompanying text.

62 Michael M. O'Hear, The Original Intent of Uniformity in Federal Sentencing, 74 U. CIN. L. REV. 749, 808 (2006). The Supreme Court softened the harshness of some sentencing guidelines systems through its decisions in Blakely v. Washington, 542 U.S. 296 (2004), and United States v. Booker, 543 U.S. 220 (2005), both of which recognized the right of defendants to jury fact-finding of factors that increase sentencing exposure. See Booker, 543 U.S. at 231 (holding that state sentencing scheme violated defendant's rights and that statutory maximum must be based solely on facts reflected in jury verdict or admitted by defendant); Blakely, 542 U.S. at 303 (“[T]he 'statutory maximum' . . . is the maximum sentence a judge may impose solely on the basis of the facts reflected in the jury verdict or admitted by the 
from jurisdiction to jurisdiction, but, in many, Gerard Lynch's characterization of plea bargaining would be apt: administrative justice has replaced adversarial and the prosecutor now occupies the primary role in adjudicating guilt and setting punishments. ${ }^{63}$ In plea bargaining, then, the prosecutor may be perceived by defendants less as a negotiating partner and more as the key decisionmaker.

In short, there are good reasons to suspect that the procedural justice effects documented in so many other settings do, indeed, apply to the decisions of prosecutors in making and responding to plea offers.

2. Translating Procedural Justice Into Plea Bargaining Process Norms. As indicated above, the Tyler model identifies four factors as attributes of procedural justice: voice, neutrality, trustworthiness, and respect. ${ }^{64}$ How might these factors be translated into plea bargaining practice? Let us consider each in turn.

Defendants have voice to the extent they perceive an opportunity to tell their side of their story. Interestingly, some research suggests that voice matters even if the opportunity to be heard does not occur until after the relevant decision has been made. ${ }^{65}$ Voice effects are greater, however, if the opportunity to be heard is provided earlier in the process. ${ }^{66}$ Prosecutors should thus ensure such an opportunity is available before presenting an offer to a defendant.

defendant."). Mandatory minimums, however, are exempted from this rule. See Harris v. United States, 536 U.S. 545, 565 (2002) ("[T]he facts guiding judicial discretion below the statutory maximum need not be alleged in the indictment, submitted to the jury, or proved beyond a reasonable doubt."). Moreover, even after the federal guidelines were converted from mandatory to advisory in Booker, federal judges continued to follow them with nearly the same frequency as before. See Michael M. O'Hear, The Duty to Avoid Disparity: Implementing 18 U.S.C. $\$ 3553(a)(6)$ After Booker, 37 MCGEORGE L. REV. 627, 645 (2006) (describing Booker decision and noting that guidelines compliance and overall sentencing severity have not dramatically changed since Booker was decided).

${ }_{63}$ See Lynch, supra note 4, at 2124, 2132 (noting defendant's options are limited because of disparity in power so that defendant likely will take whatever prosecutor offers).

${ }_{64}$ See supra note 36 and accompanying text.

${ }^{65}$ See MacCoun, supra note 34, at 192-93 (concluding fairness judgments are enhanced even when there is no chance of influencing decision).

66 $I d$. at 192. 
One common method for prosecutors to learn the defendant's side of the story is through police reports. Police, however, are not always diligent about collecting the defendant's side of the story. ${ }^{67}$ Moreover, defendants may not think much of their opportunity to be heard by the police. Their "hearing," for instance, may have occurred in an emotionally charged arrest context, or may have been colored by coercive or deceptive police practices. Thus, a serious commitment to voice cannot be satisfied through an uncritical reliance on police reports. ${ }^{68}$

Instead, before making a plea offer, the prosecutor should affirmatively ascertain whether the defendant had a meaningful opportunity to convey his or her side of the story, either through appropriately sensitive police processes or through an attorney. Thus, for instance, in cases in which police documentation does not indicate meaningful voice opportunities, the prosecutor should dig a little deeper, refraining from plea negotiations until after he or she has discussed the matter with the officers involved or has provided the defendant with a meaningful voice opportunity through counsel. $^{69}$ And, to the extent that counsel is regarded as the guarantor of defendant voice, plea negotiations should wait until after the defendant and the lawyer have conferred for more than just a few moments in a crowded holding pen or the back of a noisy

67 See Paternoster et al., supra note 13, at 177 (describing study that asked arrestees: "Did the [police] officers take the time to listen to your side of the story?").

68 That said, even such an uncritical reliance might be a procedural justice improvement in some jurisdictions. For instance, a recent field study of plea negotiations in one busy urban court found that prosecutors made their initial judgment of the worth of each case based solely on information contained on the outside of the case file, consisting primarily of the charge, the defendant's criminal history, and the name of the defendant's attorney. See Hephner, supra note 19, at 57 (describing study). Moreover, "[d]ue to the large volume of cases the prosecutors viewed on a daily basis, this folder was often the only acquaintance a prosecutor had with a defendant until the plea was agreed to or until a trial date was set." Id.

69 Encouraging police to collect statements from defendants is not, of course, without risk to defendants who have a tendency to incriminate themselves when given an opportunity. See Anemona Hartcollis, Remain Silent? Some in Custody Spell It All Out, N.Y. TIMES, Jan. 5, 2007, at A1 (describing colorful examples of incriminating information supplied by defendants on standard disclosure forms). Indeed, savvier defendants, fearful of making an inadvertent damaging admission, might distrust voice opportunities provided by the police. In order to help defendants feel more comfortable with their voice opportunities, it may be helpful to treat these opportunities as privileged communications, much as Federal Rule of Evidence 410 offers protection for statements made during plea negotiations. See FED. R. EVID. 410 (stating rule on inadmissibility of statements made during negotiations). 
courtroom, as is the norm for indigent defendants in some jurisdictions. ${ }^{70}$ In support of this view, one might recall Casper's finding of a significant correlation between defendant perceptions of procedural justice and the amount of time simply spent talking with a lawyer. ${ }^{71}$

Neutrality is associated with a decisionmaker who is unbiased, honest, and principled. ${ }^{72}$ Most prosecutors doubtlessly believe they are neutral, but the trick is to reassure defendants of this. Tyler identifies the use of objective criteria as an important means by which a decisionmaker can establish his or her neutrality. ${ }^{73}$ Decisions, moreover, should be explained so as to demonstrate that a neutral process was followed. ${ }^{74}$ In the plea bargaining context, then, prosecutors might enhance procedural justice by adopting objective criteria to guide their decisions ${ }^{75}$ and explaining to

70 See Backus \& Marcus, supra note 17, at 1033-34 ("II]n Broward County, Florida, the elected public defender felt compelled last year to forbid his attorneys from advising indigent criminal defendants to plead guilty unless they have had 'meaningful contact' with their clients in advance. . . . [He stated,] 'It's not fair to make life-altering decisions while handcuffed to a chair with fifty people standing around.' ").

${ }^{71}$ See Casper et al., supra note 12, at 498 (finding that amount of time defendant spent with his or her attorney is positively related to reports of procedural fairness). In addition to time pressures, there is another difficulty with relying on counsel as a voice intermediary: what to do in cases in which the defendant wishes to tell a story that is counterproductive to his or her own best interests, at least as judged by defense counsel. Imagine, for instance, that in a close "reasonable doubt" case, the defendant wants to admit that he committed the crime but argue that the victim "had it coming." Assuming that the victim's conduct does not give rise to a valid legal defense, the lawyer is in quandary: telling the defendant's story to the prosecutor likely will not strengthen the defendant's position, and even if the admission cannot later be used against the defendant in court, it may harm the defendant by undermining the lawyer's efforts to depict him or her in a sympathetic light during plea negotiations. From a procedural justice standpoint, the defendant's desire for voice perhaps can be reasonably well satisfied by an opportunity simply to tell his or her story to a lawyer, particularly if the lawyer then explains why it might be harmful to repeat the story to the prosecutor and ultimately leaves the decision up to the defendant.

72 See Tyler \& Thorisdottir, supra note 36 , at 380 (relating neutrality with lack of bias, honesty, and principled decisionmaking).

73 Tyler, supra note 35, at 298.

74 See id. (stating openness and explanation tend to show evidence of neutrality).

75 Gary Lowenthal describes the adoption of such criteria by the Maricopa County Attorney in Arizona: line prosecutors were required to seek a prison sentence "for every defendant who displayed a gun or knife in the commission of a crime," and prohibited from reducing residential burglaries from felonies to misdemeanors. GARY LOWENTHAL, DOWNAND DIRTY JUSTICE: A CHILLING JOURNEY INTO THE DARK WORLD OF CRIME AND THE CRIMINAL COURTS 39 (2003). A somewhat more nuanced set of criteria would be preferable. See infra notes 164-78 and accompanying text. Indeed, the procedural justice concerns discussed here would provide further support for the sort of prosecutorial guidelines that long have been of 
defendants why they take the positions they do. Explanations ought to be conveyed through defense counsel, but, recognizing that busy counsel may not effectively convey the information, prosecutors also should explain their reasoning in open court when the defendant is physically present to offer his or her guilty plea. ${ }^{76}$

People infer trustworthiness when they believe "that the authorities with whom they are dealing are concerned about their welfare and want to treat them fairly." ${ }^{\prime 7}$ Perceived trustworthiness is enhanced when the authorities demonstrate that they have actually considered the information offered during voice opportunities. $^{78}$ Thus, in the plea bargaining context, when explaining his or her positions, the prosecutor should expressly address any claims asserted by the defendant in support of more lenient treatment, ${ }^{79}$ that is, provide what was termed "principled engagement" above. ${ }^{80}$

Perceptions of respect are associated with simple politeness by the authorities, as well as the acknowledgement of citizens' legal

interest to academics as a counterweight to sentencing guidelines. See Ronald F. Wright, Sentencing Commissions As Provocateurs of Prosecutorial Self-Regulation, 105 COLUM. L. REV. 1010, 1012(2005) (discussing how academics "have looked optimistically to prosecutorial guidelines as the next frontier for sentencing commissions to explore"). I provide a more detailed proposal for the use of prosecutorial guidelines so as to enhance perceptions of procedural justice in Michael M. O'Hear, Plea Bargaining and Victims: From Consultation to Guidelines, 91 MARQ. L. REV. (forthcoming 2007) (manuscript at 9-13, on file with author), available at http:/papers.ssrn.com/sol3/papers.cfm?abstract_id=1005373.

${ }_{76}$ To be sure, explanations do not always make decisions more palatable, and may sometimes have the reverse effect. An adverse decision that is poorly justified may leave a worse impression than an entirely unexplained decision for which it may be possible to imagine a good explanation. Consider, for instance, the defendant's response when a prosecutor justifies a less-than-generous plea offer by reference to vague rumors that the defendant belongs to a street gang-rumors that the defendant knows to be false and malicious. In such a case, the defendant's respect for the system might actually be higher if plea-bargaining remained within the proverbial black box. On the other hand, in the black box scenario, defendants may be unlikely to give prosecutors the benefit of the doubt and to assume that some good explanation lies behind an adverse decision. Moreover, given a need to provide a public justification for the plea offer, prosecutors presumably will tend to avoid explanations that are facially implausible, readily demonstrated to rest on false premises, or lacking a rational connection to the recognized purposes of the criminal justice system.

77 Tyler, supra note 38 , at 441.

78 See id. ("Without considering their arguments, people believe that the authority cannot be acting benevolently ....").

79 See Tyler \& Thorisdottir, supra note 36, at 383 ("But people do need to feel that their views have been actively considered. Authorities can facilitate such feelings by accounting for their decisions in the respondent's own terms.").

80 See supra note 28 and accompanying text. 
rights. $^{81}$ In the plea bargaining context, prosecutors might undertake a number of measures to enhance perceptions of respect. They might, for instance, take care to use the appropriate honorific when referring to the defendant (e.g., Mr. Smith, Ms. Jones) and discourage unnecessary handcuffing and other forms of rough treatment. $^{82}$ They also should avoid exploding offers that expire before defendants have had a meaningful opportunity to confer with counsel or to litigate colorable suppression motions as such offers convey a disregard for the defendants' legal rights. Finally, after formal charges have been filed, prosecutors should avoid threats of enhanced charges in order to extract guilty pleas. ${ }^{83}$ A guilty plea represents the waiver of numerous constitutional rights, including the right to a jury trial and the privilege against selfincrimination. $^{84}$ A prosecutor shows disrespect for these rights when she threatens a recalcitrant defendant with charges that she evidently did not think appropriate to pursue in the first instance. ${ }^{85}$

B1 See Tyler, supra note 38, at 440 (stating people respond to "whether they are treated with respect, politeness, and dignity, and whether their rights as citizens are acknowledged").

${ }_{82}$ Such basic forms of respectful treatment of criminal defendants are more routinely observed in other Western nations. See JAMES Q. WHITMAN, HARSH JUSTICE: CRIMINAL PUNISHMENT AND THE WIDENING DIVIDE BETWEEN AMERICA AND EUROPE 8 (2003) (discussing France and Germany's commitment to giving criminal offenders respect and dignity).

83 For a well-known example of a case in which a prosecutor did so, see Bordenkircher $v$. Hayes, 434 U.S. 357, 358 (1978). In some jurisdictions, the use of such threats seems to be common. See, e.g., MCCOY, supra note 18, at 180 (noting lawyers' observation that threats of charging under California habitual offender law were "often used in plea bargaining to elicit a quick guilty plea"). Indeed, charging threats have been effectively institutionalized in some prosecutors' offices. For instance, in King County, Washington, the policy is to charge conservatively at first: the prosecutor's office "only files charges on the offense that it is quite confident it can win at trial, does not add additional charges just because the facts may allow for it, and does not add enhancements." Bowen, supra note 19, at 78 . If the defendant does not plead guilty quickly, though, additional charges and enhancements are filed in preparation for trial. Id. at 79. For instance, in drug dealing cases, school bus zone sentence enhancements generally are sought only against defendants who choose not to accept the prosecutor's take-it-or-leave-it plea proposal. Id. at 97.

84 See Boykin v. Alabama, 395 U.S. 238, 243 (1969) (stating guilty pleas involve waiver of certain constitutional rights).

85 Robert Scott and William Stuntz have a wonderful analogy for Bordenkircher, the leading charging threat case, that nicely captures this aspect of the prosecutor's actions:

The ... analogy is ... the lone gas station in the middle of the desert that charges fifty dollars for a gallon of gas. Like the prosecutor in Bordenkircher, the gas station usually gets its asking price, because the difference between that price and the cost of going without (death in the desert) is so high. . . Imagine, however, that the gas station owner goes further. Figuring that the buyer will kick and scream and haggle for an 
In sum, it is not hard to imagine a number of conceptually simple protocols that could be implemented by prosecutors in order to enhance defendants' perceptions of procedural justice: (1) before starting plea negotiations, ensure that defendants have had a meaningful opportunity to tell their side of the story, either through police officers during pre-charge processing or through counsel after charging; (2) develop objective criteria to guide plea negotiations; (3) explain positions taken in negotiations; (4) expressly acknowledge arguments for more lenient treatment; and (5) refrain from pressure tactics like exploding offers and charging threats. These five measures will be referred to here as the "procedural justice norms" in plea bargaining. I leave for Part IV, below, a consideration of the potential costs of these norms, which, as we will see, may have important implications for the way that they are implemented. ${ }^{86}$

Before moving on, one additional matter should be addressed: whether defendants ought to be given a remedy for violations of the procedural justice norms. Because there is little experience in this country with enforceable rules of charging or plea bargaining, ${ }^{87}$ it is difficult to know to what extent enforceability would contribute to prosecutorial compliance, on the one hand, or give rise to costly disruptions in case processing, on the other. The answers, in fact, may vary significantly by jurisdiction, depending, for instance, on the culture and organization of each prosecutor's office. ${ }^{88}$ In the end, the enforceability issues require considerably more experimentation and empirical analysis. ${ }^{89}$ For present purposes, I will assume that

hour, but will eventually agree to the seller's price, the seller decides to cut the negotiation short by letting the air out of the buyer's tires and offering to refill the tires if, but only if, the buyer pays the seller's asking price for gas.

Robert E. Scott \& William J. Stuntz, Plea Bargaining as Contract, 101 YALE L.J. 1909, 1964 (1992).

86 See infra notes 153-90 and accompanying text.

87 Perhaps the most notable example is New Jersey's "Brimage guidelines." See Ronald F. Wright, Prosecutorial Guidelines and the New Terrain in New Jersey, 109 PENN ST. L. REV. 1087, 1097 (2005) (noting how attorney general "reined in the available plea offers and limited the factors considered during plea negotiations" in New Jersey).

${ }^{88}$ For a general description of approaches to internal governance and policy enforcement in prosecutor offices, see ROY B. FLEMING ET AL., THE CRAFT OF JUSTICE: POLITICS AND WORK IN CRIMINAL COURT CoMmUNITIES 56-59 (1992).

${ }_{89}$ The difficulties are illustrated by the experience with the U.S. Department of Justice's internal guidance documents for federal prosecutors. Lacking judicial enforcement mechanisms, some of the Department's guidelines have been "repeatedly violated." See Ellen 
procedural justice norms could be effectively implemented by most prosecutors' offices through routine methods of internal training and supervision, without a need to devise special enforcement mechanisms. ${ }^{90}$

3. Salience of Procedural Justice Effects to Criminal Law. While theorists continue to debate the proper purposes of criminal punishment, there can be little doubt that the contemporary American criminal justice system embraces crime control as a central, if not the central, objective. ${ }^{91}$ With this overarching objective in mind, this Part will consider how implementation of the procedural justice norms may contribute to the effectiveness of the criminal justice system. Before proceeding, though, it may be helpful to distinguish more clearly between two levels at which procedural justice is believed to operate. In Tyler's model, procedural justice enhances both compliance with specific, individualized directives of legal authorities (for instance, the orders included in a final judgment entered in a particular criminal case) and compliance more generally with the legal system and its requirements (for instance, the general requirement that citizens obey the dictates of a jurisdiction's criminal code).$^{92}$

S. Podgor, Department of Justice Guidelines: Balancing "Discretionary Justice," 13 CORNELL J.L. \& PUB. POL'Y 167, 176-85 (2004) (discussing reported violations of Petite Policy, grand jury advisement policy, and guidelines on presentation of exculpatory evidence to grand jury). Yet, even some critics of the Department's compliance history concede that the existing guidelines structure "serve[s] important interests of educating new personnel in the office, providing consistency within offices, and also providing a structure for important internal policy decisions." Id. at 194. Thus, the development of " soft' remedies" may be preferred to "strict judicial oversight and correction," which might lead the Department to get out of the guidelines business altogether. Id. at 195 .

${ }_{90}$ Cf. Luna, supra note 34, at 603-05 (advocating adoption by police and prosecutors of clear principles to guide exercise of law enforcement discretion, but without judicial enforcement).

${ }_{91}$ See, e.g., 18 U.S.C. $\$ 3553(a)(2)$ (2000) (requiring that, at sentencing, federal judges consider need for sentence imposed in order to, inter alia, "promote respect for the law," "afford adequate deterrence," and "protect the public from further crimes of the defendant"); N.Y. PENAL LAW § 1.05(6) (Consol. 2007) (establishing societal protection, rehabilitation, and deterrence as purposes of penal sanctions); see also Richard S. Frase, State Sentencing Guidelines: Diversity, Consensus, and Unresolved Policy Issues, 105 ColuM. L. REV. 1190, 1206 (2005) ("Although [sentencing] guidelines are often viewed as deliberately, and perhaps inherently, designed to emphasize retributive goals of proportionality and uniformity, all state guideline reforms, even at their inception, have also given substantial weight to crime control purposes.").

92 See Tyler, supra note 35, at 283-84 (arguing that process-based model of regulation encourages general and specific legal compliance). 
The criminal justice system depends on voluntary compliance by defendants at both levels. Consider first the level of individualized directives. It may seem odd to suggest that there is something important about voluntary defendant compliance with the judgments reached in criminal cases. After all, the criminal justice system has at its disposal the state's most powerful tools of coercion: an army of police officers, all manner of sophisticated investigative tools and techniques, laws threatening severe penalties for noncompliance, and of course, a capacious network of unpleasant jails and prisons. Yet, the system does require high levels of compliance to reach its aspirations. We can see this need most clearly in cases that result in a sentence of probation.

Probation plays an integral role in the criminal justice system; at any given time many more defendants are on probation than in jail or prison. ${ }^{93}$ Probation is almost invariably conditioned on the defendant doing certain things (e.g., undergoing treatment for addiction, participating in other rehabilitative programming, submitting to regular drug testing, or performing community service) and not doing others (e.g., avoiding contact with other convicts, avoiding contact with victims, or not engaging in further criminal conduct) ${ }^{94}$ These conditions generally are not arbitrary, but are instead easily connected to important, express purposes of the criminal justice system: crime prevention, rehabilitation, and just punishment. ${ }^{95}$ Yet, probation conditions frequently are violated.$^{96}$ This gives rise to two important problems. First, to the extent that violations go undetected or unsanctioned by authorities-an occurrence believed to be quite common given the

93 See lauren E. Glaze \& Seri Palla, U.S. Dep'T of Justice, Probation and Parole IN THE UNITED STATES, 2004, at 1, available at http://www.ojp.gov/bjs/pub/pdf/ppus04.pdf (2005) (showing at end of 2004, more than four million offenders were on probation, while number in jail or prison was just over two million).

94 See 18 U.S.C. $\$ 3563$ (2000) (listing mandatory and discretionary conditions of federal probation); Howard ABADINSKY, PROBATION AND PAROLE: THEORY AND PRACTICE 109-12 (3d ed. 1987) (discussing standard conditions of probation).

${ }_{95}$ See 18 U.S.C. \& 3553(a)(2) (2000) (listing purposes of punishment in federal cases); ABADINSKY, supra note 94, at 130 ("In general, the courts can impose any conditions of probation that are reasonably related to the rehabilitation of the offender ... or the protection of the community ....").

96 See GLAZE \& PALLA, supra note 93, at 6 (indicating that only sixty percent of people discharged from probation in 2004 successfully met conditions of their supervision). 
inadequacy of resources devoted to supervision ${ }^{97}$ - the underlying purposes of the conditions are defeated. Second, to the extent that violations are detected and sanctioned, the processes for doing so consume scarce criminal justice resources, especially when the offender is sent to prison as a result of the violation. ${ }^{98}$ Both problems would be diminished by enhanced voluntary compliance with probation conditions.

Even with respect to sentences of incarceration, compliance is a matter of substantial concern, for reasons going well beyond the potential for defendants to abscond. Prisons are not places of unlimited coercion and control. ${ }^{99}$ Violent disturbances remind us of this in particularly dramatic form, ${ }^{100}$ as do pervasive problems of substance abuse among the incarcerated. ${ }^{101}$ Prisons, particularly outside the maximum security setting, provide varying, and not insignificant, levels of autonomy. ${ }^{102}$ This state of affairs seems inevitable, not only as a result of resource constraints, ${ }^{103}$ but also as a result of the need to prepare most inmates eventually to reenter free society. Indeed, the vocational training and other rehabilitative programming available in many prisons would be of little value if prisoners failed to accept their sentences, persistently resisted prison authorities, and required constant, close supervision. ${ }^{104}$ In short, without significant measures of acceptance and voluntary

97 ABADINSKY, supra note 94, at 108.

98 See id. at 121-26 (describing typical probation revocation process).

99 See SPARKS ET AL., supra note 34, at 303 ("Prison staff are in fact frequently rather keenly aware of the need to tailor their actions, demeanour, and demands in recognition of prisoners' customary expectations-and their capacity to resist.").

100 See Anthony E. Bottoms, Interpersonal Violence and Social Order in Prisons, in PrIsons 205, 226 (Michael Tonry \& Joan Petersilia eds., 1999) (collecting data on homicide in prison).

${ }_{101}$ See Chase Riveland, Prison Management Trends, 1975-2025, in PrIsons, supra note 100, at 163, 187 ("Any candid prison administrator ... will admit that the effort to control illegal substances . . . is unending.").

${ }_{102}$ See Bottoms, supra note 100 , at 272 ("From one perspective, being a prisoner among prisoners is a lifestyle that requires continual choices.").

${ }^{103}$ See id. at 210 ("[(1]n most day-to-day situations) prisoners heavily outnumber prison officers; and . . . to many prisoners, the incentives or disincentives ... that the prison system offers have little real meaning.").

104 See Gerald G. Gaes et al., Adult Correctional Treatment, in PRISONS, supra note 100, at 361 (discussing wide range of treatment programs in use); Riveland, supra note 101, at 179 (noting importance of mental health treatment in prison and potential value of cognitive therapy, anger management, and substance abuse treatment programs recently adopted in many prisons). 
compliance, there seems little likelihood that prisons can accomplish their objectives of maintaining a safe, orderly environment and preparing prisoners for successful reentry to society. ${ }^{105}$

Compliance also matters in the second, more general sense of an internalized feeling of obligation to obey the law and cooperate with legal authorities. Such an attitude plainly furthers crime-reduction goals. To be sure, much of the political rhetoric surrounding crime control in recent years has emphasized the coercive strategies of deterrence and incapacitation, in lieu of the value-internalization suggested by Tyler. ${ }^{106}$ Yet, neither the public nor the legal system has ever entirely abandoned hope in rehabilitation. ${ }^{107}$ For instance, parole, which is premised on rehabilitation, ${ }^{108}$ continues to play a central role in the criminal justice systems of many states. ${ }^{109}$ Moreover, much evidence suggests a resurgence of interest in rehabilitative approaches. ${ }^{110}$ The widespread embrace of drug treatment courts and victim-offender mediation programs across the nation, for instance, evinces a desire for alternatives to the heavyhanded threats embodied in so much "get-tough" sentencing legislation of the $1980 \mathrm{~s}$ and $1990 \mathrm{~s} .{ }^{111}$ In short, retribution and

105 Interestingly, precisely these sorts of concerns were an important motivating factor behind the adoption of the federal sentencing guidelines in the 1980s; it was believed that anger over unfair sentences contributed to prison violence and impaired rehabilitation. O'Hear, supra note 62 , at 763-64, 773 .

106 See, e.g., FrankLin E. ZImRIng et al., Punishment and Democracy: Three STRIKes AND YOU'RE OUT IN CALIFORNIA 91 (2001) (identifying incapacitation as initial purpose of California's "three strikes" law adopted in 1994); O'Hear, supra note 62, at 787 (identifying deterrence as chief purpose of federal sentencing reforms adopted in 2003).

107 See Joan Petersilia, Parole and Prisoner Reentry in the United States, in PRISONS, supra note 100, at 479, 518 ("Recent research reveals that the public favors both punishing and treating criminals ...."); see also id. at 518-22 (discussing several recent parole reform initiatives that offer enhanced social services for parolees).

${ }_{108} I d$. at 482-83. Parole traditionally has provided job assistance, family counseling, and chemical dependency programs, although such programs have tended to suffer from budget cuts in recent years. Id. at 483 .

${ }^{109}$ Although the long-term trend has been towards discontinuing or restricting the availability of parole release, most states retain parole in some form. See id. at 496 (providing state-by-state data). Indeed, several states that "abolished" parole later reestablished it or an equivalent. Id. at 482 .

${ }^{110}$ Michael Tonry, Obsolescence and Immanence in Penal Theory and Policy, 105 CoLUM. L. REV. 1233, 1252-54 (2005); see also Vincent Schiraldi \& Judith Greene, Reducing Correctional Costs in an Era of Tightening Budgets and Shifting Public Opinion, 14 FED. SENT'G REP. 332, 332-33 (2002) (discussing public opinion with respect to prevention, rehabilitation, and sentencing).

111 See Michael M. O'Hear, Federalism and Drug Control, 57 VaND. L. REV. 783, 823-25 
deterrence in and of themselves do not provide anything close to a complete account of American criminal justice today. Assuming that it does advance crime control objectives, there is no reason to believe that Tyler's legitimacy-based model is fundamentally incompatible with the spirit and purpose of our criminal justice system.

Thus far, I have offered what the theorists would call a consequentialist defense of procedural justice in plea bargaining. However, there are those who reject consequentialism in favor of deontological approaches to criminal justice. ${ }^{112}$ While mounting a full-blown deontological defense of procedural justice is beyond the scope of this Article, I suggest a couple of reasons why even those in the deontological camp might regard my proposed procedural justice norms -if not my underlying reasoning - with sympathy. First, for one who views the criminal justice system's overriding purpose as the identification of, and imposition of just punishment on, the morally culpable, there must be some appreciation of more robust procedure from its accuracy-enhancing standpoint. For instance, defendant voice may help to produce timely information that prevents wrongful convictions or disproportionate punishments. ${ }^{113}$ Indeed, the classic deontological critique of a deterrence-based criminal law is that deterrence theory is said to be overly accepting of punishments imposed on the factually innocent. ${ }^{114}$ Second, even to the extent that procedural justice fails to advance accuracy interests, those favoring a deontological approach may nonetheless be receptive to arguments for procedural reform that are themselves grounded in theories of political morality. A full elaboration of this approach will have to await another day, but one may indeed find considerable support for at least some aspects of the proposed plea bargaining norms in the Kantian tradition of political theorizing. ${ }^{115}$

(2004) (discussing drug treatment courts); Mark S. Umbreit et al., Restorative Justice in the Twenty-First Century: A Social Movement Full of Opportunities and Pitfalls, 89 MARQ. L. REV. 251, 259-61 (2005) (discussing victim-offender mediation).

112 In criminal law scholarship, the deontological approach centers on the retributive view that "punishment is justified solely because the person being punished deserves it." Russell L. Christopher, Deterring Retributivism: The Injustice of "Just" Punishment, 96 NW. U. L. REV. 843, 845 n.1 (2002).

${ }_{113}$ See infra notes $186-90$ and accompanying text.

114 Christopher, supra note 112 , at 848.

115 Jerry Mashaw's dignitary theory of process is perhaps the most influential and welldeveloped effort to ground procedural rights in the liberal tradition of political morality. 
We should not, in short, regard procedural justice in plea bargaining as a lost cause even on the deontological side of the great divide in criminal law theory.

\section{DOUBTS ABOUT DISTRIBUTIVE JUSTICE}

If the demands of distributive justice were reasonably determinate, we mightjustifiably decide to prioritize these demands over those of procedural justice. ${ }^{116}$ Indeed, Tyler himself has suggested that the fairness heuristic effect-that is, the tendency of people to rely on procedural justice judgments in one transaction as a cognitive shortcut to predict whether outcomes in future

Mashaw begins with a basic moral premise of individual autonomy: "Each citizen is an end in himself, not merely a means for the attainment of collective ends. The government cannot, therefore, pursue its purposes through processes which ignore the independent status and purposes of the individual." JERRY L. MASHAW, DUE PROCESS IN THE ADMINISTRATIVE STATE 45 (1985). Arising from this premise, Mashaw identifies comprehensibility of government action as a fundamental process value in a liberal democracy. Id. at 172-73. Dovetailing with Tyler's procedural justice model, Mashaw's notion of comprehensibility encompasses "reason giving" (explanation) as an important obligation of government decisionmakers. See id. at 176, 199 ("[R] eason giving confirms the participant, even in the face of substantive disappointment, as engaging in an ongoing process of rational and selfregarding action."). Mashaw also notes the value of individual participation (voice) in the decisionmaking process, albeit in a more qualified fashion. See id. at 178, 200 (discussing role of participation in contributing to individual self-respect). For another effort to establish a Kantian foundation for explanation and voice, see Edmund Pincoffs, Due Process, Fraternity, and a Kantian Injunction, in DUE PROCESS: NOMOS XVIII, at 172, 175-79 (J. Roland Pennock \& John W. Chapman eds., 1977).

Markus Dirk Dubber has suggested a similar argument specifically in the plea bargaining context, identifying a deep tension between plea bargaining as commonly practiced in the United States and the basic Enlightenment project of legitimizing criminal punishment through procedures that show respect for the defendant's moral autonomy. See Dubber, supra note 5, at 591-92, 595-96 (discussing reformation of plea bargaining). He notes with interest the arguments of some German scholars that more robust participation by the defendant might render plea bargaining "consistent with the autonomy of the accused," and thus better legitimize the practice. $I d$. at $604-05$.

For a more detailed argument that the ends of retributive and procedural justice may be viewed in a complementary way, see O'Hear, supra note 75, manuscript at 6-8.

116 By "distributive justice," I refer generally to the justness of outcomes. See Casper et al., supra note 12, at 486 (establishing perception of outcome justness as affecting defendants' overall perception of courtroom experience). In the criminal law context, it is perhaps more conventional (though hardly universal) to use the term "retributive justice" as a way of describing preferred outcomes. However, because this term implies a particular theory of punishment that may not be broadly accepted, I prefer a more open-ended term that is intended to encompass whatever may be the preferred measure of the justness of outcomes. 
transactions will generally be fair ${ }^{117}$-rests precisely on the indeterminacy of distributive justice relative to procedural justice. ${ }^{118}$ Consistent with this hypothesis, empirical research suggests that procedural justice effects in criminal trials are considerably less where the defendant's guilt or innocence is clear than where the correct verdict is in doubt. ${ }^{119}$ In light of such research, if we had a high degree of confidence in the justice of plea-bargained outcomes, then we might find procedural justice a matter of comparatively little concern.

But how should we evaluate the outcomes? There would likely be broad consensus as to at least one distributive principle: plea bargaining should not result in the conviction of the factually innocent. This one principle, though, supplies little meaningful guidance in the great run of cases in which the factual elements of the defendant's guilt of something are readily satisfied. Troubling distributive justice questions pervade such cases. In expansive criminal codes with many overlapping offenses, what is the correct offense or offenses of conviction? What should be done in cases in which the defendant, though factually guilty, might nonetheless plausibly win acquittal as a result of the suppression of key evidence or jury nullification? Should sentencing be addressed in the plea agreement, and, if so, how? ${ }^{120}$

117 See Tyler \& Lind, supra note 37 , at 76-77; see also supra notes 51-53 and accompanying text.

${ }_{118}$ Tyler \& Lind, supra note 37 , at 80 ("Most people are . . . much better at perceiving whether they are being treated impolitely than they are at interpreting whether the fine they received or the judgment handed down in their lawsuit is fair.").

119 Linda J. Skitka \& David A. Houston, When Due Process Is of No Consequence: Moral Mandates and Presumed Defendant Guilt or Innocence, 14 SOC. JUST. RES. 305, 315-16 (2001); see also Heuer, supra note 11, at 221 (discussing studies indicating that disrespectful treatment may be perceived as fair response to inappropriate behavior).

120 Viewing plea bargains as consensual transactions, one might argue that their voluntariness per se satisfies the requirements of distributive justice. However, this perspective disregards the interests of third parties such as victims, the community, the defendant's family, and so forth, whose consent is not required to consummate a plea deal. To be sure, the judge may attend to these interests in plea acceptance and sentencing proceedings, but this is not the same thing as third-party consent and merely begs the distributive justice questions of which third-party interests are legitimate and how each should be weighed relative to others. Moreover, as many commentators have observed, in light of pervasive disparities in bargaining power, information, and cognitive abilities, it is far from clear that informed consent fairly characterizes the position of most defendants who accept plea deals. See, e.g., Julian A. Cook, III, All Aboard! The Supreme Court, Guilty Pleas, and the Railroading of Criminal Defendants, 75 U. CoLO. L. REV. 863, 906-13 (2004) 
In recent literature, one common approach has been to use trial outcomes as a benchmark. ${ }^{121}$ As Ronald Wright has put it, "[a] healthy system would aspire to replicate through its guilty pleas the same pattern of outcomes that trials would have produced." ${ }^{122}$ While illuminating in some respects, the approach has important limitations. ${ }^{123}$ For instance, as criminal trials become increasingly rare in many jurisdictions, it becomes more difficult to use predicted trial outcomes as a benchmark. ${ }^{124}$ Moreover, the trial distortion approach says nothing about what may be the most important and difficult distributive justice question in plea bargaining: how large of a discount should the defendant receive from the expected trial result in return for his or her guilty plea? Finally, the approach accepts uncritically the mix of substantive criminal law, procedural rules, and judge and juror proclivities that produce trial outcomes, even though one of the potential benefits of plea bargaining is the possibility of overcoming some of the features of formal doctrine and legal processes that tend to produce unsatisfactory results. ${ }^{125}$

Yet, theory seems to provide no more satisfactory a framework than expected trial results. Basic purposes of punishment are a contested matter and not infrequently point in different directions. ${ }^{126}$ Deontological (more specifically, retributive) approaches are said to hold sway at present among academic

(discussing inequities in plea bargaining process).

121 See, e.g., Bibas, supra note 5, at 2468 ("Plea-bargaining practices need many reforms to conform more closely to the shadows of trial ....").

122 Wright, supra note 3 , at 83.

123 For a more extended discussion of Professor Wright's "trial distortion" theory, see generally Michael M. O'Hear, What's Good About Trials?: A Response to Trial Distortion and the End of Innocence in Federal Criminal Justice, 156 U. PA. L. REV. 209 (2007).

124 See Wright, supra note 3 , at 83 n.12 (finding that lack of trials could lead to bargaining abuses).

${ }_{125}$ See PAUl H. Robinson \& Michael T. CAHILl, LAW WiThout JUSTICE: Why CRIMINAL LAW DOESN'T GIVE PEOPLE WHAT THEY DESERVE 82 (2006) ("The claim that bargains do not resemble the proper formal legal sanctions available is problematic from a desert perspective only if the law on the books tracks desert better than the bargains do. Yet in an era of everexpanding criminal prohibitions and ever-escalating criminal penalties, there is reason to suspect this is not the case.").

${ }_{126}$ See, e.g., Michael M. O'Hear, Sentencing the Green-Collar Offender: Punishment, Culpability, and Environmental Crime, 95 J. CRIM. L. \& CRIMINOLOGY 133, 250-52 (2004) (discussing debates over deterrence as appropriate purpose of punishment and identifying inconsistencies between deterrence- and culpability-based approaches in punishment of environmental crimes). 
commentators, ${ }^{127}$ but such consensus at a broad level of abstraction (even if it really exists and is relevant) masks important areas of dissensus as to what retributivism really requires of the criminal justice system. ${ }^{128}$

But perhaps there is yet hope that we can bridge the divide between retributive and consequentialist approaches. As I have argued elsewhere, Paul Robinson and his collaborators have developed a promising means of doing so. ${ }^{129}$ Indeed, because his approach shares the same root concerns with perceived legitimacy and law-abidingness that animate Tyler's work, Robinson's theory merits some particular attention here.

Drawing on his own body of social scientific research, Robinson argues that crime control ends are most effectively advanced through policies that enhance public respect for the criminal justice system and that this goal is best achieved by adhering to one particular brand of retributive proportionality, that is, the calibration of punishment with public views of the relative blameworthiness of different types of criminal conduct. ${ }^{130}$ Implementing his approach in a systematic way would require a considerable amount of empirical research on public attitudes towards different forms of criminality-research whose feasibility has been called into question by some commentators. ${ }^{131}$ According to Robinson, however, existing research indicates that "[p]eople can and do agree-not always, but usually, and more often than one

127 See Christopher, supra note 112, at 846-47 (noting that retributivism has been endorsed by legislatures, courts, and scholars).

${ }^{128}$ See, e.g., ROBINSON \& CAHILL, supra note 125, at 19-20 (noting differences between "desert pragmatists" and "desert moralists," and describing controversy over whether resulting harm should affect punishment).

129 O'Hear, supra note 126, at 155-56.

130 ROBINSON \& CAHILL, supra note 125, at 17; Paul H. Robinson \& John M. Darley, The Utility of Desert, 91 Nw. U. L. REV. 453, 457 (1997). For an example of recent empirical work lending support to Robinson's theory, see Janice Nadler, Flouting the Law, 83 TEX. L. REV. 1399, 1402-03 (2005).

131 Stephen Breyer, The Federal Sentencing Guidelines and the Key Compromises Upon Which They Rest, 17 HOFSTRA L. REV. 1, 16 (1988) (noting that members of U.S. Sentencing Commission rejected proposal to base sentencing guidelines on public views of desert because they "believed that public polling was not sufficiently advanced or detailed to warrant its use as accurate sources in ranking criminal behaviors"). 
might think-about what constitutes deserved punishment in specific cases."132

Even granting this contention, however, there are important limitations on the usefulness of Robinson's approach as a source of distributive norms for plea bargaining. For instance, it is unclear what should be done with crimes about which public values are uncertain, evolving, deeply conflicted, or subject to considerable regional variation, which might include such large and important components of the criminal docket as drug and gun offenses. Nor is it clear, as Robinson himself concedes, how to manage the implicit trade-offs in plea bargaining between achieving desert in the case at hand and showing lenience so as to secure a guilty plea and conserve resources for doing justice in other cases. ${ }^{133}$ There also are conceptual difficulties in translating a ranking of relative crime severity-which is where Robinson locates the public consensus on which he relies ${ }^{134}$-into a scale of actual punishment. We all may agree that simple robbery should be punished less than armed robbery and more than theft from person, but within those parameters, what exactly should the prosecutor demand by way of a sentence in any given robbery case ${ }^{135}$ Finally, what should be

\footnotetext{
132 ROBINSON \& CAHILL, supra note 125 , at 14.

133 See id. at 84 ("As yet, we have at best incomplete answers to these critical questions.").

134 See id. at 14 (stating that people assess relative blameworthiness by placing cases in rank order).

135 Robinson would respond to this concern by arguing that additional criteria may be developed to distinguish among those who have committed the same crime and that once the full range of distinctions among all offenses are mapped on a scale anchored by the minimum and maximum possible penalties, there will, in fact, be a discrete, narrow range of punishment that will be associated with each degree of blameworthiness of the defendant's conduct. See Paul H. Robinson, The Role of Moral Philosophers in the Competition Between Deontological and Empirical Desert, 48 WM. \& MARY L. REV. 1831, 1835 (2007) ("[E]mpirical desert does not produce an indeterminate range of punishment, as some have suggested, but rather a specific amount."). This, however, suggests a scheme of enormous complexity, reminiscent of the federal sentencing guidelines, which have been heavily criticized on precisely these grounds. See, e.g., Michael M. O'Hear, The Myth of Uniformity, 17 FED. SENT'G REP. 249 (2005) (illustrating problems with length and detail in U.S. Sentencing Guidelines' attempts at uniformity). Moreover, even to the extent that consensus over relative offense severity can be successfully translated into a usable, comprehensive, ordinal scale, the consensus may break down over the appropriate anchoring points, which would be a function of preferred overall severity. As Robinson has suggested, disagreements over general punishment severity mask the ordinal consensus, Robinson, supra, at 1835, and raise important conceptual and practical difficulties over how to account for community-tocommunity variation in preferred overall severity when evaluating plea deals.
} 
done in those cases in which public views of a just outcome diverge sharply from those of the defendant, the victim, or both? Robinson is deeply concerned with public views of the legitimacy of the criminal justice system, but the public simply pays no attention to the mine run of cases. Defendants and victims, however, do pay attention to even the most routine of cases, so perhaps we ought to weigh their views of distributive justice more heavily than those of the inattentive public. ${ }^{136}$

This suggests yet another approach to distributive justice: plea bargains might be judged according to how well they satisfied the expectations of the parties in the case. Empirical research indicates that the fairness of outcomes tends to be assessed by reference to expectations. ${ }^{137}$ What might shape defendant expectations as to the plea bargain? Unfortunately, there is no simple, clear answer to this question. Repeat offenders surely will look to their own past experience as a guide to what a just outcome would be in a new case. ${ }^{138}$ Additionally, empirical research indicates that defendants' assessments of fairness are influenced by whether their outcomes compare favorably with those of others convicted of the same crime. ${ }^{139}$ Expectations also may be shaped by conversations with defense counsel, promises made by law enforcement officers, earlier plea deals struck with codefendants, and so forth. In any given case, the defendant may have no clear basis upon which to form an expectation or may receive conflicting signals from a variety of different sources. ${ }^{140}$ Victims likewise may receive conflicting signals

${ }^{136}$ See HEUMANN, supra note 19, at 169 ("I suspect that in most communities a 'zone of indifference' surrounds court practices. Within this zone, the community is indifferent to how and why cases are plea bargained or tried." (footnotes omitted)).

${ }^{137}$ O'Hear, supra note 5, at 866; see also James H. McGinnis \& Kenneth A. Carlson, Offenders' Perceptions of Their Sentences, 5 J. OFFENDER COUNSELING, SERVICES \& REHABILITATION 27, 35 (1981) ("These data [gathered in prison inmate interviews] indicate that offenders' perception of their sentences as lenient or severe is a function of the deviation of the sentences from their expectations.").

138 Felony defendants typically do have prior involvement with the criminal justice system. See, e.g., Casper et al., supra note 12, at 488 (noting that in sample of 411 felony defendants only twelve percent had never been arrested before).

139 Id. at $486,494$.

140 In one study of one hundred inmates in an Ontario prison, researchers found that forty-two based their sentence expectations on information received from their lawyers, while fifty-five looked to their own personal knowledge of the criminal justice system. McGinnis \& Carlson, supra note 137, at 32-33. Underscoring the difficulty of using offender expectations as a measure of distributive justice, the researchers found a remarkably high 
or no signal at all, and may develop expectations that diverk" significantly from those of defendants. Indeed, this line of distributive justice analysis may bring us back around to part of the procedural justice agenda: if prosecutors develop and use objective criteria in a transparent way in their plea bargaining, this not only should reassure participants in the criminal justice system that prosecutors are neutral and trustworthy (procedural justice values), but also should help condition participant expectations and better ensure that outcomes match expectations (a distributive justice value). In the absence of such criteria, however, an expectationsbased view of distributive justice would not supply an especially clear means of assessing plea bargaining outcomes.

Although a comprehensive treatment of distributive justice in plea bargaining lies beyond the scope of this Article, I hope that this Part at least has conveyed some of the important difficulties. This is not to say, however, that the quest for distributive justice is futile. We may lack a single, determinate, consensus principle to guide the analysis, but in any given case, there likely will be some outcomes that seem reasonably consistent with a number of the different approaches to distributive justice and other outcomes that seem inappropriate from nearly any principled perspective. While it generally may be defensible for prosecutors to surrender a solid second-degree murder charge in return for a manslaughter plea, I suspect it is only very rarely appropriate to make the same deal for a plea to simple assault. Still, as is indicated by empirical research, ${ }^{141}$ there seems to be more than enough play in the distributive justice joints for procedural justice to matter to criminal litigation participants and thus to warrant greater attention from scholars and practitioners of plea bargaining.

\section{COLLATERAL BENEFITS: TRANSPARENCY TO THIRD PARTIES}

Thus far this Article has focused on one set of procedural justice benefits, that is, those arising from the enhanced acceptance of plea bargaining outcomes and perceptions of legitimacy among

degree of variance in expected sentences, considerably higher than the variance of actual sentences (standard deviation of 21.26 months versus 9.95 months). Id. at 32 .

141 See infra notes 224-30 and accompanying text. 
defendants. One set of collateral benefits, however, also merits consideration: the procedural justice norms I have proposed will increase the transparency of the plea bargaining process to interested third parties, including victims and the community at large. Although actual conversations between prosecutors and defense counsel will remain private, the reasoning process underlying plea deals will be more open to system outsiders; the objective criteria prosecutors employ will be publicly available while case-specific explanations of deals and acknowledgements of defendants' arguments for lenience will be articulated in court during plea acceptance hearings.

Although victims traditionally have been excluded from the plea bargaining process, there is no reason to believe they would respond to procedural justice in plea bargaining any differently than defendants - that is, by exhibiting increased acceptance of outcomes, enhanced perceptions of system legitimacy, and increased lawfulness. While perhaps not conventionally conceptualized as within the core objectives of the criminal justice system, these effects seem not only clearly beneficial in their own right, but also consistent with the system's growing attentiveness to victims' needs. ${ }^{142}$ Of course, offering victims meaningful voice opportunities in plea bargaining gives rise to administrative challenges quite distinct from those presented by defendant voice. ${ }^{143}$ For that reason, a full consideration of procedural justice for victims in plea bargaining lies beyond the scope of this Article. For now, though, it seems reasonably clear that victim-centered procedural norms would dovetail in some important respects with the defendantcentered norms proposed here. More specifically, using objective

142 See Douglas E. Beloof, Judicial Leadership at Sentencing Under the Crime Victims' Rights Act: Judge Kozinski in Kenna and Judge Cassell in Degenhardt, 19 FED. SENT'G REP. 36, 37 (2006) (describing recent legislative successes of victims' rights movement and arguing that victims' participatory rights in criminal justice system are now well-established); Michael M. O'Hear, Victims and Criminal dustice: What's Next?, 19 FED. SENT'G REP. 83, 86-87 (2006) (noting proposal of victims' rights advocate to expand victim participation in plea bargaining and arguing that victims' rights agenda represents implicit rejection of narrowly focused deterrence and retribution agenda in favor of new "harmreduction" paradigm of criminal justice).

${ }^{143}$ For a recent discussion of these problems, see generally Simon N. Verdun-Jones \& Adamira A. Tijerino, Four Models of Victim Involvement During Plea Negotiations: Bridging the Gap Between Legal Reforms and Current Legal Practice, 46 CANADIAN J. CRIMINOLOGY \& CRIM. JUST. 471 (2004). 
criteria and providing explanations of plea deals would help assure victims, just as much as defendants, of the neutrality and trustworthiness of prosecutors. ${ }^{144}$

Such transparency also might contribute to greater perceived legitimacy in the eyes of the public. Although problems with the accuracy and proportionality of outcomes have dominated recent scholarly literature on plea bargaining, ${ }^{145}$ transparency and accountability to the public have also figured prominently in the discussion. ${ }^{146}$ Public opinion surveys consistently find low approval rates of plea bargaining. ${ }^{147}$ Leading commentators have argued that plea bargaining causes the public to lose confidence in the criminal justice system, ${ }^{148}$ and that public distrust of plea bargaining has been manipulated by politicians to gain support for dubious criminal justice reforms. ${ }^{149}$ While it remains difficult to isolate the public's principal objection to plea bargaining, there are good reasons to believe that the secretiveness of the practice greatly contributes to the negative perceptions. ${ }^{150}$ Measures that enhance the

144 The limited empirical research on victims and plea bargaining does provide some support for the hypothesis that greater transparency enhances victim satisfaction. See MCCOY, supra note 18, at 204 n.5 (reporting study showing "some increase ... in victim satisfaction with the court process" when "allowed to be present at plea bargaining sessions"). For a more detailed discussion of victims and plea bargaining, see generally O'Hear, supra note 75 .

${ }_{145}$ See supra note 5 and accompanying text.

146 See, e.g., Stephanos Bibas, Transparency and Participation in Criminal Procedure, 81 N.Y.U. L. REV. 911, 913-16 (2006) (identifying gulf between "insiders" and "outsiders" in criminal justice system); Sergio Herzog, Plea Bargaining Practices: Less Covert, More Public Support?, 50 CRIME \& DELINQUENCE 590,590-92 (2004) (discussing public's negative attitude with respect to plea bargaining); Wright \& Miller, supra note 15, at 33-34 (discussing public's loss of faith in plea bargaining system). As suggested above, my view is that some scholars may overemphasize the significance of the perceptions of a largely inattentive public relative to those of defendants and victims. See supra note 136 and accompanying text. This is not to say, however, that public perceptions ought to be regarded as wholly irrelevant to plea bargaining reform.

147 See MCCOY, supra note 18, at 64-65 (discussing two studies that "point toward some general concerns underlying public dissatisfaction with the guilty plea process"); Herzog, supra note 146, at 590-91 (noting three studies in which large majority of respondents $(80 \%, 82 \%$, and $64 \%$ ) did not support plea bargaining).

148 See Wright \& Miller, supra note 15, at 33 ("The public in general, and victims in particular, lose faith in a system where the primary goal is processing and the secondary goal is justice.").

149 See McCoY, supra note 18, at 33-36 (discussing political context of plea bargaining).

150 See id. at 67 ("[T] f fact that the sentencing decisions are made behind closed doors creates its own unfortunate impression."); Herzog, supra note 146, at 591 (noting arguments that convertness and secretiveness of plea bargaining reduces public confidence). 

transparency of plea bargaining therefore may contribute to the criminal justice system's perceived legitimacy, ${ }^{151}$ or, at the very least, better inform misguided public debate over the practice. ${ }^{152}$

\section{RESPONDING TO OBJECTIONS}

Objections to the proposed procedural justice norms in plea bargaining will likely fall into two categories: (1) implementing the norms would have adverse effects on the operation of the criminal justice system and (2) procedural justice in plea bargaining is not capable of delivering the benefits suggested by the social psychology model. These objections are detailed below along with responses to each major concern. Although some of the objections do raise important, unanswered questions as to implementation of the procedural justice norms, they are not nearly so compelling on their face to justify a definitive conclusion that the costs of procedural justice in plea bargaining outweigh the benefits. ${ }^{153}$

\section{A. OBJECTIONS BASED ON ADVERSE EFFECTS}

1. The Transaction Costs of Procedural Justice Will Undermine Efforts to Achieve Distributively Just Outcomes. Incremental procedure entails incremental transaction costs. Assuming criminal justice budgets remain constant, the pursuit of procedural justice in plea bargaining may leave fewer resources available for other purposes, thus potentially affecting the ability of the criminal justice system to achieve distributively just outcomes (even taking into account the modesty with which distributive justice claims should

151 Lending some modest support to this hypothesis, a recent study of Israeli attitudes toward plea bargaining found that greater openness regarding the purposes of plea bargaining was capable of increasing public support for the practice, albeit not by a large margin. Herzog, supra note 146, at 606.

${ }_{152}$ For a recent, more detailed account of the costs of opacity in the criminal justice system, see Bibas, supra note 146, at 945-52.

${ }^{153}$ I operate here in utilitarian, cost-benefit balancing mode. As suggested above, however, it is possible to conceptualize procedural justice in plea bargaining as a moral mandate. See supra note $\mathbf{1 1 5}$ and accompanying text. I leave a more complete elaboration of this theory for another day, but note for now that there is at least a plausible basis for implementing some elements of procedural justice in plea bargaining even in the absence of a persuasive cost-benefit showing. 
be advanced). For instance, as resources of prosecutors arc stretched, they may simply choose not to pursue as many cases or may offer ever more generous plea bargains so as to further reduce the number of resource-intensive trials. Alternatively, prosecutors may shift resources to cases that are easy to prosecute (e.g., drug and gun possession, routine street crime) and away from cases that are more complex though perhaps no less important (e.g., sophisticated financial fraud, environmental crime, transnational drug trafficking). Or prosecutors may attempt to enhance their plea bargaining leverage by lobbying for legislative reforms that would increase sentences or broaden the scope of criminal liability. ${ }^{154}$ These, and any number of other conceivable prosecutorial responses, threaten to skew patterns of charging, plea bargaining, and sentencing in ways that may undercut the ability of the criminal justice system to deliver criminal punishment in ways proportionate to the severity of the offense, consistent across similar cases, and otherwise responsive to public priorities.

Carried to an extreme-say, offering defendants and other interested parties unlimited opportunities to speak in court and requiring a written, point-by-point response to all factual and legal contentions--procedural justice surely would conflict in substantial and troubling ways with other important objectives. This does not mean, however, that a more modest yet still meaningful procedural justice agenda raises similar concerns. The following parts consider in turn each of the proposed procedural justice norms.

a. Voice. Prosecutors should seek to ensure that defendants have a meaningful opportunity to convey their side of the story before making a plea offer. ${ }^{155}$ Implementing this proposal, however, would not be without its difficulties. For instance, while defense lawyers might seem the most appropriate vehicle for defendant voice, case volumes and economic constraints often leave defense

${ }^{154}$ See William J. Stuntz, The Pathological Politics of Criminal Law, 100 MicH. L. REV. 505, 537-38 (2001) (discussing lobbying efforts of prosecutors). To note that prosecutors may seek legislation is not to say they will necessarily get it. As Darryl Brown has shown through recent empirical research, "legislatures routinely decline proposals for new crimes or greater punishments." Darryl K. Brown, Democracy and Decriminalization, WASH. \& LEE LEGAL STUDIES PAPER No. 2006-07, at 4 (Sept. 2006), available at http://ssrn.com/abstract= 932667.

${ }^{155}$ See supra note 66 and accompanying text. 
counsel with no more than a few minutes to interact with many of their clients before court appearances ${ }^{156}$-nowhere near enough time to establish a relationship of trust with the client, ${ }^{157}$ obtain a complete version of the client's side of the story, explore potential defenses, and discuss plea bargaining objectives and tactics. In some jurisdictions, then, public defense budgets may require significant increases if lawyers are to provide meaningful voice opportunities for their clients without substantially slowing down the processing of cases.

As a lower-cost alternative, prosecutors might work with police to develop processes to provide voice before formal charging. ${ }^{158}$ One possibility would be for police to offer all defendants an opportunity to provide a post-arrest written statement that would be appended to the official police report and included in the prosecutor's case file. ${ }^{159}$ An important difficulty is that so many defendants suffer from impediments to effective written communication: low levels of education ${ }^{160}$ poor cognitive functioning, ${ }^{161}$ lack of fluency in English ${ }^{162}$ and so forth. Paraprofessionals could be made available to provide assistance, but this might significantly increase transaction costs in high-volume jurisdictions. Alternatively, prosecutors might screen written statements to identify those

156 See supra notes 25, 70 and accompanying text.

157 See BOGIRA, supra note 25, at 125-26 (noting distrust defendants tend to feel regarding public defenders); LOWENTHAL, supra note 75, at 93 (noting gender, ethnicity, and other barriers between public defender and client).

${ }^{158}$ This is not to say that police necessarily will conform to unilateral prosecutorial directives. Police and prosecutors have a complicated, interdependent relationship. See, e.g., Daniel Richman, Prosecutors and Their Agents, Agents and Their Prosecutors, 103 CoLUM. L. REV. 749, 758-94 (2003) (describing prosecutor-agent relationships in federal system). Still, prosecutors typically do have some sway with police in light of their formal role as gatekeepers to the courthouse, $i d$. at 758-67, and, in any event, police should be as interested as prosecutors in procedural justice reforms that are capable of increasing acceptance of criminal punishment and decreasing recidivism rates.

159 Decisions would have to be made, and clearly communicated to defendants, as to whether and how such statements could be used against them in legal proceedings. See supra note 69 and accompanying text.

160 See Thomas C. O'Bryant, The Great Unobtainable Writ: Indigent Pro Se Litigation After the Antiterrorism and Effective Death Penalty Act of 1996, 41 HARV. C.R.-C.L. L. REV. 299, 309-10 (2006) (noting lack of education among prisoners).

161 Id.

162 See Christopher E. Smith, The Malleability of Constitutional Doctrine and Its Ironic Impact on Prisoners' Rights, 11 B.U. PUB. INT. L.J. 73, 89 (2001) (noting that many prisoners often are not fluent in English). 
requiring additional follow-up by defense counsel in light of obvious problems with written communication.

Experimentation and empirical research will doubtlessly suggest additional voice alternatives. It is not clear what the most costeffective approach will prove to be. Indeed, the answer will probably vary by jurisdiction, depending on such factors as the size and composition of the criminal case docket, police-prosecutor relations, and the structure and location of pretrial detention facilities. Yet, there does seem to be some promising avenues for ensuring at least minimal levels of voice without incurring overwhelming costs.

\section{b. Objective Criteria, Explanation, and Principled} Engagement. Prosecutors can reassure defendants of their neutrality and trustworthiness by employing objective criteria in making plea bargaining decisions, explaining their decisions, and demonstrating consideration of defense arguments in favor of lenience (even if such arguments are ultimately rejected). Such measures would potentially give rise to at least three types of cost: prosecutor time, outcome rigidity, and reduced deterrence.

Time costs need not be great. Objective criteria can be developed on an office-wide basis. The rapidity with which plea bargains are routinely struck in high-volume jurisdictions ${ }^{163}$ suggests that relatively few variables are regarded as significant in most cases, ${ }^{164}$ and that those variables already are well understood by experienced practitioners. ${ }^{165}$ Reducing those variables and their weight to written form as general plea bargaining guidelines should not be

163 See Abbe Smith, Too Much Heart and Not Enough Heat: The Short Life and Fractured Ego of the Emphatic, Heroic Public Defender, 37 U.C. DAVIS L. REV. 1203, 1256 (2004) (noting that public defenders often only meet clients and arrange guilty pleas).

164 This is consistent with psychological research on decisionmaking. See R. Barry Ruback \& Jonathan Wroblewski, The Federal Sentencing Guidelines: Psychological and Policy Reasons for Simplification, 7 PSYCHOL. PUB. POL'Y \& L. 739, 756 (2001) ("Rather than being complexly determined, most decisions can be explained by only two or three factors, because of limitations in how much information individuals can remember and process.").

165 See FEELEY, supra note 19, at 187-88 (comparing plea bargaining to supermarket in which "customers may complain about prices, but rarely 'bargain' to get them reduced"). Lending support to this hypothesis of a clear going rate based on a small number of variables, a recent study conducted in one urban courthouse found that the lawyers surveyed were able to correctly predict the final outcome of most cases upon being told only the crime of conviction, the defendant's criminal history, and the identity of the lawyers in the case. Hephner, supra note 19 , at 44-45, 55; see also HEUMANN, supra note 19, at 103 (describing five factors that "weigh heavily" in classification of cases as serious or non-serious by prosecutors). 
unduly burdensome. ${ }^{166}$ Nor should it be especially time-consuming to provide case-specific explanations based on those variables or acknowledge defendants' arguments. ${ }^{167}$

Rigidity concerns are more troubling. The use of objective criteria inevitably will produce plea bargaining rules that are both over- and under-inclusive, since no set of objective criteria can hope to capture the full range of considerations that seem morally relevant in all cases. Gary Lowenthal supplies a nice illustration from his experience as a prosecutor in Maricopa County, Arizona, where the County Attorney's "deadly weapon" policy required prosecutors to seek a lengthy prison term in any case in which a gun had been discharged:

In a case prosecuted by one of my colleagues . . . a middle-aged man with steady employment, an intact family and no prior criminal record had fired a gun over the heads of his two teen-age sons to "get their attention" when they were fighting in front of their home. Although no one was hurt and the two sons were horrified that their father was being prosecuted, the most lenient plea bargain my colleague could offer required the father to serve at least five years in prison. This made no sense to me. The man had certainly exercised poor judgment . . . but his conduct also reflected an otherwise law-abiding parent's frustrated response to an emotionally charged situation. Although he may have committed the same crime as a gang leader shooting a gun in the direction of members of a rival gang, their punishments should not have been determined in a one-size-fits-all fashion. ${ }^{168}$

\footnotetext{
166 Indeed, it is not uncommon for prosecutorial offices to do so already, although often in a less systematic, transparent fashion than would be ideal. See, e.g., HEILBRONER, supra note 32, at 41 (noting policy of Manhattan prosecutor's office that sentences should increase with each arrest); LOWENTHAL, supra note 75, at 39 (describing Maricopa County deadly weapons policy).

${ }_{167}$ Explanation and acknowledgment may be delivered to defense counsel and in open court. See supra notes $75-76$ and accompanying text.

168 LOWENTHAL, supra note 75 , at 40.
} 
Lowenthal's example shows how the use of objective criteria-like whether a gun was discharged-can produce outcomes that are difficult to justify from any distributive justice standpoint. ${ }^{169}$ Indeed, a rigid adherence to harsh, over-inclusive plea bargaining rules seems hard to square with the procedural justice goal of perceived trustworthiness, that is, the perception that the authorities care about defendants' welfare and want to treat them fairly. ${ }^{170}$

The rigidity problem exposes a point of tension within procedural justice theory that has not been adequately addressed in social psychology literature. ${ }^{171}$ However, this problem has been dealt with extensively in the abundant scholarly literature on sentencing guidelines. ${ }^{172}$ The preferred approach in the sentencing context is that objective criteria set presumptive sentences or sentencing ranges, with some measure of equitable discretion preserved to override presumptive outcomes in unusual cases. ${ }^{173}$ The presumptive approach seems readily adaptable to plea bargaining guidelines and may provide a good model for addressing tensions between neutrality and trustworthiness. ${ }^{174}$

\footnotetext{
${ }^{169}$ See also HEILBRONER, supra note 32, at 42 (describing one case in which application of prosecutorial policy of seeking increased sentence for each arrest would have resulted in two-month jail term for failing to pay one-dollar subway fare, prompting judge to give tonguelashing to prosecutor).

170 See Tyler, supra note 38, at 441 ("[P]eople value evidence that the authorities with whom they are dealing are concerned about their welfare and want to treat them fairly.").

171 Mashaw has succinctly characterized the dilemma in connection with his "dignitary" procedure value of rationality:

A concern for rationality . . . leads to concerns about inconsistency and arbitrariness. Yet the routines that make consistency possible in bureaucracies are among our prime examples of irrational behavior-the wooden inability to respond to differences in context. We thus seem to confront a choice between the irrationality of bureaucratic control and the irrationality of official discretion.

MASHAW, supra note 115, at 203.

172 See, e.g., R.A. Duff, Guidance and Guidelines, 105 CoLUM. L. REV. 1162, 1164-81(2005) (concluding that rigid numerical sentencing guidelines are too constraining); Kyron Huigens, Solving the Williams Puzzle, 105 COLUM. L. REV. 1048, 1068-79 (2005) (discussing advantages of discretionary sentencing schemes over determinable sentencing schemes).

173 See Kevin R. Reitz, The New Sentencing Conundrum: Policy and Constitutional Law at Cross-Purposes, 105 COLUM. L. REV. 1082, 1102-04 (2005) (discussing presumptive sentences with potential departures from norm).

174 Ronald Wright, who also argues for prosecutorial guidelines structured in this way, observes that New Jersey's guidelines already reflect this approach. Wright, supra note 87, at 1103.
} 
The use of objective criteria in plea bargaining also may give rise to concerns that deterrence will be compromised. Imagine, for instance, that a prosecutor's office adopted a (not unreasonable) policy of recommending straight probation in return for a guilty plea in cases involving first-time possession of a personal-use quantity of marijuana. An express policy to this effect might be interpreted as a free pass for marijuana users and thereby undercut deterrence for those who have not yet been convicted for the first time. On the other hand, given the low risks of apprehension for many common types of crime and the tendency towards over-optimism among offenders, there are good reasons to doubt the strength of deterrence effects even in the absence of such plea bargaining rules. ${ }^{175}$ Moreover, repeat offenders, as well as those defendants who have had family members and friends suffer prosecution, already are likely to have a pretty good idea of what sorts of plea deals are available for which types of defendants; they do not need written rules to know where the safe harbors are. For other offenders, particularly those with high social status, the risks of arrest and conviction alone, regardless of sentence, will be an effective deterrent. ${ }^{176}$ Finally, to the extent that plea bargaining rules do, in fact, diminish deterrence in some respects, there will be countervailing deterrence benefits, as the rules (such as Maricopa County's "deadly weapon policy") ${ }^{177}$ will highlight those particularly dangerous or undesirable forms of conduct that prosecutors most wish to deter. ${ }^{178}$

175 For a more detailed discussion of reasons to be skeptical of deterrence, see Paul $\mathrm{H}$. Robinson \& John M. Darley, The Role of Deterrence in the Formulation of Criminal Law Rules: At Its Worst When Doing Its Best, 91 Geo. L.J. 949, 953-56 (2003).

${ }^{176}$ See Carolyn N. Ko, Note, Civil Restraining Orders for Domestic Violence: The Unresolved Question of "Efficacy," 11 S. CAL. INTERDISC. L.J. 361, 388 (2002) (noting social status has effect on likelihood that arrest will have deterrent effect).

177 See LOWENTHAL, supra note 75 (describing policy).

178 To the extent one believes that criminal punishment in America is already too harsh, one might fear another cost of transparency: once the public understands the magnitude of the guilty plea discount given to some offenders, the public will demand even longer sentences. As Stephanos Bibas recently observed, however, the harshness of public attitudes likely to a considerable extent is caused by opacity, and transparency actually may help alleviate the problem. Bibas, supra note 146, at 958. Moreover, as noted above, public attitudes never have been as uniformly punitive as is sometimes believed, and now may be shifting in a more constructive direction. See supra notes 107-11 and accompanying text. 
c. Avoidance of High-Pressure Tactics. Because it is connccted to the perception that authorities take legal rights seriously, respect. seems incompatible with the use of high-pressure tactics by prosecutors to extract quick guilty pleas, such as the use of threats of increased charges or exploding offers that expire before defendants have an opportunity to confer adequately with their lawyers. ${ }^{179}$ Prohibiting such practices, however, might make it at least marginally more difficult for prosecutors to consummate quick plea agreements, potentially leading to higher trial rates and concomitant burdens on an overtaxed criminal justice system. ${ }^{180}$

Elsewhere, I have explored at length the potential consequences of a ban on charging threats. ${ }^{181}$ In brief, while it is impossible to predict the effects of regulating pressure tactics with precision, trial rates likely would rise slightly, but probably not dramatically. The rate of increase would be constrained by: (a) the manifest advantages to most defendants of pleading guilty, ${ }^{182}$ and (b) the potential for prosecutors to maintain their plea negotiation leverage by increasing initial charges, lobbying the legislature for harsher sentencing statutes and other self-serving new laws, or both. ${ }^{183}$ To be sure, these potential prosecutorial responses may be troubling and costly in their own right. On the other hand, there also are apt to be ancillary benefits, such as improved case screening by prosecutors, before charges are filed. ${ }^{184}$

Moreover, to whatever extent plea bargaining reforms do increase trial rates, we should bear in mind that trials do not necessarily represent a net loss. A trial may result in the acquittal of an

179 See supra notes 82-85 and accompanying text.

180 On the other hand, psychology research has documented the potential for negotiations to break down if one side is perceived to be acting unfairly. See, e.g., Christine Jolls et al., $A$ Behavioral Approach to Law and Economics, 50 STAN. L. REV. 1471, 1494 (1998) (citing Matthew Rabin, Incorporating Fairness Into Game Theory and Economics, 83 AM. EcoN. REV. 1281 (1993)) (indicating people are willing to sacrifice their own wellbeing for those who act fairly and to punish those who act unfairly); see also O'Hear, supra note 5, at 866, 893 (applying these studies to plea bargaining). It is conceivable, then, that prosecutorial pressure tactics sometimes misfire and that reducing the use of such tactics accordingly may have little net effect on trial rates.

181 See id. at 891-901 (describing six possible options prosecutors might take in absence of charging threats).

${ }_{182}$ See supra notes 32-33 and accompanying text.

${ }^{183}$ See O'Hear, supra note 5, at 892 (describing possible responses to absence of charging threats, including increasing initial charges).

${ }_{184}$ See id. at 894 (noting early review of merits of case would be welcome development). 
innocent defendant who otherwise would have buckled under prosecutorial pressure and pled guilty. A trial may provide an opportunity for a jury, representing the voice of the community, to signal disapproval of otherwise opaque prosecutorial charging practices. A trial provides potentially valuable voice opportunities for victims and defendants ${ }^{185}$ and may result in useful sanctioning of police misconduct, as by the suppression of evidence gathered in violation of the Fourth Amendment. More generally, a trial offers far more information than a plea hearing to interested parties and the public about alleged criminal conduct, the human consequence of crime, and the activities of police and prosecutors.

d. Complementarity of Procedural and Distributive Justice. Although the costs do not seem unmanageable, some jurisdictions will doubtlessly find it challenging to implement the procedural justice norms. Slower case processing and the expectation of increased effort by prosecutors, even if small on a per case basis, may add up such that it becomes more difficult to achieve important distributive justice goals, such as prosecuting and obtaining a conviction in all cases involving serious social harm referred to prosecutors by the police. To recognize the possibility of tradeoffs between procedural and distributive justice, however, is not to concede that procedural justice and the important benefits it offers from the standpoint of acceptance, legitimacy, compliance, transparency, and law-abidingness must give way. Moreover, it is important to recognize that procedural and distributive justice, while in tension in some respects, may in other respects actually complement one another.

Consider, for instance, how voice may contribute to distributive goals. Timely information from the defendant may prevent a wrongful conviction or otherwise help the prosecutor reach a better judgment about an appropriate resolution for the case. As Alafair Burke recently has observed, psychology research indicates that prosecutors are apt to develop anti-defendant cognitive biases once a decision to charge is made. ${ }^{186}$ Other commentators have observed

\footnotetext{
185 It is easy, however, to overestimate the voice qualities of real-world criminal trials. See infra notes 237-40 and accompanying text.

${ }^{186}$ See Alafair S. Burke, Improving Prosecutorial Decision Making: Some Lessons of Cognitive Science, 47 WM. \& MARY L. REV. 1587, 1614 (2006) ("In the context of prosecutorial decision making, the biasing theory is the prosecutor's belief that the defendant is guilty.
} 
how prosecutors, given their position in the law enforcement system, tend to develop strongly negative attitudes towards defendants as a class. ${ }^{187}$ Providing meaningful voice opportunities early in the process may help the prosecutor to avoid biases, overcome stereotypes, and better appreciate the strength of any legal and factual defenses that are available, as well as any equitable considerations that might appropriately influence resolution of the case ${ }^{188}$ These positive effects of voice only would be strengthened by the further requirements that prosecutors actually consider what defendants say and then explain their decisions.

Other aspects of procedural justice also are capable of delivering distributive justice benefits. Part III.c explained how the use of objective criteria would advance the distributive goal of more consistently satisfying defendant and victim expectations. ${ }^{189}$ Meanwhile, the avoidance of high-pressure tactics may help diminish the risk that innocent defendants will feel coerced into pleading guilty. ${ }^{190}$

In sum, it is far from clear that the proposed procedural justice norms would result in an overall loss on the distributive justice side of the ledger, let alone that the distributive justice costs would outweigh the procedural justice benefits.

2. The Process Is the Punishment: Bringing Procedural Justice to Plea Bargaining Undermines the Invisible Punishment on Which the System Relies. The absence of procedural justice marks criminal defendants as devalued and undeserving of the community's full regard. Yet it might be objected this is precisely as it should be: the

Once that belief is formed, confirmation bias causes her to seek information that confirms the theory of guilt ....").

187 See, e.g., LOWENTHAL, supra note 75, at 111 ("Prosecutors are at the center of a culture that abhors defendants and those around them. Every day, they interact with police officers who see themselves to be at war with criminals . . . . Crime victims, another important constituency, often have wrenching personal stories and cannot fathom why the courts allow their tormenters to get off lightly. Exposed to these views, prosecutors often develop a black and white view of the world.").

188 In addition to the value of the information produced by the defendant, any delays for procedural justice purposes also may serve the cause of accuracy by giving more time for useful information to become available from other sources. See MCCOY, supra note 18, at 160 (noting common attorney view "that the chances of mistake in assessing case facts are greater the younger the case").

${ }_{189}$ See supra notes $137-41$ and accompanying text.

190 See O'Hear, supra note 5, at 899-900 (noting advantages to defendants spared from charging threats). 
whole point of punishment is to degrade the defendant, creating deterrent effects, or, if you prefer the retributive viewpoint, correcting the moral imbalance created by the defendant's degradation of his victim. As Malcolm Feeley famously observed nearly three decades ago, the process of criminal prosecution may itself be viewed as part of the punishment-indeed, in many lowlevel cases, the process may be the only meaningful punishment experienced by the offender. ${ }^{191}$ Bringing greater procedural justice to plea bargaining would give defendants something they do not deserve, thereby diluting society's message of condemnation. ${ }^{192}$

The argument is rather unattractive, at least insofar as it condones "punishment" prior to a determination of guilt through formal legal processes. Of course, most defendants who engage in plea bargaining do end up pleading guilty, and most of those who plead guilty likely are guilty. But no one claims the system is foolproof. Indeed, as suggested earlier, an absence of procedural justice in plea bargaining actually may enhance the risk of wrongful

191 See FEELEY, supra note 19, at 30-31 ("In essence, the process itself is the punishment. The time, effort, money, and opportunities lost as a direct result of being caught up in the system can quickly come to outweigh the penalty that issues from adjudication and sentence.").

192 The argument addressed here is that, by diminishing the dignitary harms inflicted during criminal case processing, enhanced procedural justice might inappropriately lessen the process-based punishment received by some offenders. The converse, however, also might be argued; that is, one might object that enhanced procedural justice inappropriately would increase process-based punishment. This objection would focus particularly on a discrete class of defendants: those who have been accused of low-level crimes unlikely to result in a sentence of incarceration but who nonetheless are unable to make bail. Their punishment is, in effect, the amount of time they must wait in jail for resolution of their cases. To the extent that procedural justice results in slower case-processing, these defendants will experience a de facto increase in punishment unrelated to the actual severity of their crimes. Even more troubling, as Josh Bowers has argued, an important subset of these defendants-recidivists charged with petty crimes-includes those who are most likely to be wrongly accused. See Josh Bowers, Punishing the Innocent, 156 U. PA. L. REv. (forthcoming 2008) (manuscript at 8, on file with author), available at http://papers.ssrn.com/ sol3/papers. cfm?abstract_id=983819 (" $[\mathrm{R}]$ ecidivists are overrepresented among innocent defendants and probably comprise the majority of the population because institutional biases select for their arrest, prosecution, and trial conviction."). It seems particularly unjustifiable to increase the process-based punishment of those who are innocent but plead guilty anyway to avoid an extended period of pretrial detention. These concerns supply another reason to minimize the transaction costs of procedural justice, see supra Part IV.A.1, and may warrant some relaxation of procedural justice norms for petty crimes. To the extent that procedural justice nonetheless materially delays the consummation of deals in petty cases, defendants who cannot make bail at least should be afforded an opportunity to enter an open guilty plea as expeditiously as possible. 
conviction. ${ }^{193}$ Thus, the assumption that most defendants are guilty anyway hardly seems a satisfactory justification for unnecessarily rough treatment before guilt is formally established.

Moreover, when the process itself is conceptualized as a sanction, punishment acquires an ad hoc, opaque character. "Process punishment" may be administered in diverse ways by a variety of actors, not only the prosecutor during plea bargaining, but also (by the same reasoning) the arresting police officer, jailers, the judge who sets bail, and so forth. Who can keep track of all the rough treatment that is dished out prior to conviction and sentencing and ensure some degree of overall proportionality between the offense and the punishment? Although it may be too much to expect that the norms of procedural justice will be rigorously observed by all actors throughout the criminal process, a due regard for proportionality, accountability, and the rule of law counsels against legitimizing rough treatment prior to conviction as a valid form of "punishment." ${ }^{194}$ Indeed, doing so would seem inconsistent with the emphasis on transparency and uniformity that has dominated the punishment policy agenda since the $1970 \mathrm{~s} .{ }^{195}$

3. Procedural Justice May Result in Less Favorable Deals for Defendants. It is a familiar complaint about procedural rights that recognizing such rights may actually work to the substantive detriment of those whom the rights are nominally supposed to protect. ${ }^{196}$ Similarly, we might hypothesize that enhanced procedural justice in plea bargaining may result in less favorable deals for defendants. After all, a reduction in procedural burdens may be precisely what the prosecutor is bargaining for-the more effort the prosecutor must invest in plea bargaining, the lower the transaction costs avoided by entering into the deal. The prosecutor,

${ }^{193}$ See supra note 186 and accompanying text.

194 See James Q. Whitman, Making Happy Punishers, 118 HaRv. L. REV. 2698, 2716-17 (2005) (book review) (discussing dangers of retributive punishment degenerating into "animalistic" vengeance).

${ }^{195}$ See Michael M. O'Hear, Localization and Transparency in Sentencing: Reflections on the New Early Disposition Departure, 27 HAMLINE L. REv. 357, 366-69 (2004) (noting importance of uniformity and transparency in sentencing guidelines).

196 See, e.g., MASHAW, supra note 115, at 33-35 (discussing how welfare recipients may have been harmed by enhanced constitutional due process rights surrounding termination of benefits). 
presumably, will then demand greater concessions from the defendant in the plea offer.

Framed this way, though, the argument misses the point of the procedural justice effect: Outcomes are not the only things that matter to defendants; fair treatment along the way may count just as much or even more. The argument will have to be revised in one of two ways. First, even taking into account the moderating effects of procedural justice, defendants may still be left in an overall worse position as a result of less generous plea offers. Second, procedural justice effects may be discounted entirely as a form of false consciousness that induces defendants to accept otherwise unacceptable outcomes. ${ }^{197}$

Both lines of attack, however, depend on the dubious assumption that, due to increased transaction costs, procedural justice reforms will result in less favorable deals for defendants. As indicated above, however, procedural justice in plea bargaining need not be especially costly. ${ }^{198}$ Moreover, what costs there are need not necessarily undermine prosecutors' motives to deal; indeed, it seems about as likely that prosecutors would become more generous. As William Stuntz has observed, prosecutors are not like private litigants seeking to maximize financial gain, but rather pursue a much more complicated and uncertain set of objectives. ${ }^{199}$ Many, for instance, will be concerned primarily with volume of cases processed. Given such a motive, higher per case transaction costs should make prosecutors more, not less, averse to going to trial and hence more willing to make plea bargaining concessions in order to prevent a net reduction in case volume. Similarly, those motivated by high conviction rates may also grow more trial-averse ${ }^{200}$ to the extent that plea bargaining becomes more costly, prosecutors will have fewer resources available for effective trial preparation and may have a greater desire to avoid the heightened risks of failure

197 See supra note 49 and accompanying text.

198 See supra notes 158-67 and accompanying text.

199 Stuntz, supra note 19 , at 2554.

200 See Bibas, supra note 5, at 2471 ( $([\mathrm{P}]$ rosecutors want to ensure convictions. They may further their careers by racking up good win-loss records, in which every plea bargain counts as a win but trials risk being losses. The statistic of conviction, in other words, matters much more than the sentence." (footnotes omitted)). 
presented by trial. ${ }^{201}$ Other prosecutors will be motivated primarily by a desire to achieve what they believe to be distributively just outcomes in all of their cases; increased transaction costs may not affect their plea bargaining positions at all. Indeed, as suggested above, procedural justice may lead to more generous plea bargaining by humanizing defendants in prosecutors' eyes and thereby changing prosecutors' views of distributive justice in favorable ways. ${ }^{202}$

In short, while individual results may vary, there are good reasons to doubt that defendants' circumstances would be systematically worsened by procedural justice.

\section{B. OBJECTIONS BASED ON DOUBTS ABOUT THE BENEFITS OF PROCEDURAL JUSTICE IN PLEA BARGAINING}

1. The Judge Provides the Procedural Justice. In a formal sense, the prosecutor's plea bargaining offer, even if accepted, does not conclusively resolve a criminal case. ${ }^{203}$ Rather, the judge must still perform two distinct functions: accept the plea and impose a sentence. ${ }^{204}$ In so doing, the judge will, to a greater or lesser extent, formally adhere to basic norms of procedural justice. ${ }^{205}$ Defendants,

\footnotetext{
201 To be sure, prosecutors seeking to maintain case volume and conviction rates, in lieu of sweetening the plea bargaining pot, might lobby the legislature for harsher sentencing laws or other reforms that would enhance their bargaining leverage. Such lobbying efforts might or might not be successful. See Brown, supra note 154, at 3 (noting that most legislatures decline to expand criminal laws). Even if successful, increased leverage might merely restore the status quo ante without necessarily resulting in worse outcomes for defendants.

202 See supra note 188 and accompanying text. To be sure, some defendants will use voice opportunities to advance non-credible assertions of innocence or to otherwise deny responsibility in ways that reinforce, rather than undermine, the anti-defendant biases of prosecutors. Assuming that such biases are pervasive and powerful, however, voice is unlikely to do much harm and may do some good. Moreover, competent defense lawyers may increase the likelihood of good outcomes by counseling their clients not to waste voice opportunities on patently false denials of responsibility.

${ }_{203}$ See generally Richard Neumeg, Annotation, What Constitutes "Rejection" of Plea Agreement Under Rule 11(e)(4) of the Federal Rules of Criminal Procedure, Allowing Withdrawal of Plea If Court Rejects Agreement, 60 A.L.R. FED. 621 (1982) (discussing range of potential scenarios following offer and acceptance).

204 See FED. R. CRIM. P. 11(c)(3) (providing for judicial discretion in accepting plea bargain); id. 11(b)(1)(M) (giving judicial discretion in sentencing).

${ }_{205}$ See, e.g., Santobellov. New York, 404 U.S. 257, 262 (1971) ("[T]he adjudicative element inherent in accepting a plea of guilty, must be attended by safeguards to insure the defendant what is reasonably due in the circumstances.").
} 
for instance, will be given an opportunity to speak in open court in connection with both the plea and the sentence. ${ }^{206}$ Various objective criteria will govern acceptance of the plea and sometimes determination of the sentence. ${ }^{207}$ Credible arguments for lenience will typically be addressed in the sentencing decision. ${ }^{208}$ The judge will expressly acknowledge the legal rights that the defendant waives by pleading guilty. ${ }^{209}$ Finally, in many courtrooms, there are deeply entrenched norms of decorum and courtesy. ${ }^{210}$ Perhaps all of this judicial procedural justice obviates the need for prosecutorial procedural justice.

Although judicial practices may ameliorate perceptions of unfairness, there are at least three reasons to doubt that they fully address the problem. First, in many cases, the rituals surrounding plea acceptance and sentencing lack real significance as decisionmaking processes. Guilty pleas only very rarely are rejected, ${ }^{211}$ while sentences often are effectively dictated by the terms of the plea agreement. ${ }^{212}$ Procedural justice in these contexts may thus appear an empty formality and serve only to highlight the absence of procedural justice in reaching the plea deal. ${ }^{213}$ Second, while many judges display a strong commitment to procedural justice, others treat the formalities surrounding plea acceptance and

${ }^{206}$ See, e.g., FED. R. CRIM. P. 11(b)(1) (requiring in-person guilty plea acceptance); Green v. United States, 365 U.S. 301, 304 (1961) (allowing defendant right to speak before sentencing).

207 See, e.g., 18 U.S.C. $\$ 3553(\mathrm{a})(4)$ (2000) (requiring court's consideration of sentencing guidelines in determining sentence); FED. R. CRIM. P. 11(b) (setting forth standards for guilty plea acceptance).

208 See, e.g., FED. R. CRIM. P. 32(i)(3)(B) (requiring sentencing court to address matters that are controverted).

${ }^{209}$ See FED. R. CRIM. P. 11(b)(1) (requiring court to inform defendant of rights waived by guilty plea).

${ }_{210}$ See, e.g., United States v. Kraus, 137 F.3d 447, 454-55 (1998) (holding that district court judge's answer outside courtroom to prosecutor's hypothetical question regarding sentence violated Fed. R. Crim. P. 11(c)(1)).

${ }^{211}$ See, e.g., BOGIRA, supra note 25 , at 335 (" $[1] \mathrm{n}$ their haste to bag a plea, judges at 26 th Street sometimes accept a factual basis that's devoid of facts."); Turner, supra note 5, at 208 $\mathrm{n} .28$ (noting 1985 study finding that judges reject two percent of guilty pleas).

${ }^{212}$ See, e.g., King, supra note 5, at 295 (discussing how application of federal sentencing guidelines can be manipulated through plea agreements).

${ }^{213}$ See Dubber, supra note 5, at 552 (criticizing "hypocrisy that reduces the public plea colloquy before the judge to a carefully rehearsed charade during which the participants merely enact a script that was carefully crafted in the backroom of the prosecutor's office"). 
sentencing with obvious disdain. ${ }^{214}$ It is hard to imagine that such judges are doing anything to inculcate positive perceptions of the criminal litigation process.

Finally, to the extent that the procedural justice effect arises from the development of a fairness heuristic, as Tyler and others have argued, ${ }^{215}$ procedural justice at the end of the process may be too late. Heuristic theory predicts that earlier received information should have a greater impact than later received information. ${ }^{216}$ As to fairness judgments specifically, laboratory research supports the hypothesis that such judgments are indeed most influenced by what happens earliest in the cognitive process. ${ }^{217}$ Defendants are thus apt to form their views about the fairness of the criminal justice system based on their interactions with police and prosecutors, and to assimilate their perceptions of judicial conduct to the earlier formed heuristic. ${ }^{218}$

2. Criminal Defendants Are Different. The social psychology model is derived from a host of empirical studies testing the attitudes and conduct of a great many people in a wide variety of settings, ${ }^{219}$ but perhaps the model cannot be generalized to criminal defendants. After all, defendants, as a class, have many distinguishing demographic characteristics. ${ }^{20}$ In contrast to

214 See, e.g., BOGIRA, supra note 25, at 39 (describing judge's habit of "rac[ing] through" standard admonishments to ensure voluntariness of plea and describing one case in which total of fifteen minutes was spent on accepting plea and determining sentence); Julian A. Cook, III, Crumbs From the Master's Table: The Supreme Court, Pro Se Defendants and the Federal Guilty Plea Process, 81 NOTRE DAME L. REV. 1895, 1900 (2006) (criticizing use of leading and compound questions by judges in assessment of validity of guilty pleas).

215 See supra note 51 and accompanying text.

216 Tyler \& Lind, supra note 37 , at 78.

${ }^{217}$ See id. (" $[\mathrm{F}]$ airness heuristic theory predicts that the first-received fairness information, whether it is procedural fairness information or distributive fairness information, should have greater impact that [sic] later fairness information.").

${ }^{218}$ This concern might be addressed through greater judicial involvement in crafting the plea deal, as opposed to merely accepting an already negotiated resolution. Judicial participation in plea bargaining has been the subject of considerable academic debate, Herzog, supra note 146, at 593, and is prohibited or discouraged in most jurisdictions, Turner, supra note 5 , at 202. To the extent that judicial involvement has increased,judges should be careful to attend to the procedural norms proposed in this Article.

${ }_{219}$ See generally Tyler \& Lind, supra note 37 (noting expansive research among variety of groups).

${ }_{220}$ See U.S. Dep't of Justice, Bureau of Justice Statistics Criminal Offenders Statistics, http://www.ojp.usdoj.gov/bjs/crimoff.htm\#inmates (last visited Jan. 17, 2008) (reporting demographic statistics of inmates). 
members of the general population, defendants are considerably more likely to be young and male, to belong to a racial minority group, to suffer from addiction, to have low levels of educational achievement, and so forth. ${ }^{221}$ Do general principles of social psychology apply to such a distinct social group? In particular, to the extent that Tyler's model is premised on desires to maintain social standing, ${ }^{222}$ we may justifiably question whether the model functions in the context of those who are already socially marginalized. ${ }^{223}$

The empirical research, however, indicates otherwise. Studies have found evidence of consistent procedural justice effects across categories of race, ethnicity, gender, income, and educational attainment. ${ }^{224}$ Moreover, procedural justice effects have been found in numerous studies specifically involving criminal defendants, arrestees, and prison inmates. ${ }^{225}$ Additional, albeit indirect, support for these conclusions comes from the abundant empirical literature on victim-offender mediation and other forms of "restorative justice" (R.J.). R.J., which contemplates responding to crime through processes that offer voice and respectful treatment, ${ }^{226}$ has been

221 See Casper et al., supra note 12, at 488 (noting young age, racial minority status, low education levels, and high unemployment levels of felony defendants).

S22 See supra note 50 and accompanying text.

223 In a similar vein, one might speculate that the fairness heuristic strand of Tyler's model, see supra notes 51-52 and accompanying text, might not work with defendants who, because of their marginalization, are strongly predisposed to view the legal system as unfair or who, because of mental illness, have unconventional patterns of cognitive functioning.

224 See Tyler \& Lind, supra note 37, at 73 (discussing research); MacCoun, supra note 34, at 187 (" $[\mathrm{M}]$ ost studies have found striking similarities across demographic groups in the antecedents and consequences of procedural fairness ....").

225 See, e.g., TYLER \& HUO, supra note 35, at 33 (noting that within sample studied, thirtytwo percent reported that their most recent contact with legal authorities was through being stopped by police); Anne M. Heinz, Procedure Versus Consequences: Experimental Evidence of Preferences for Procedural and Distributive Justice, in CoURTS AND CRIMINAL JUSTICE: EMERGING Issues 13, 16 (Susette M. Talarico ed., 1985) (describing study of felony defendants); Bottoms, supra note 100, at 254-56 (discussing studies of prison inmates); Casper et al., supra note 12, at 487-88 (discussing study of felony defendants); Pauline Houlden, Impact of Procedural Modifications on Evaluations of Plea Bargaining, 15 LAW \& SOC'Y REV. 267, 290 (1980) (discussing study of inmates); Jean M. Landis \& Lynne Goodstein, When Is Justice Fair? An Integrated Approach to the Outcome Versus Procedure Debate, 1986 AM. B. FOUND. RES. J. 675, 675 (1987) (discussing study of inmates); Paternoster et al., supra note 13, at 175-76 (discussing study of domestic violence arrestees); Tom R. Tyler, The Role of Perceived Injustice in Defendants' Evaluations of Their Courtroom Experience, 18 LAW \& SOC'Y REV. 51, 59 (1984) (discussing study of defendants in traffic and misdemeanor court).

${ }^{226}$ See MacCoun, supra note 34, at 177 ("[P]rocedural justice theory has played an 
found in numerous studies to produce higher levels of satisfaction and lower levels of recidivism among offender-participants than does the conventional criminal justice system. ${ }^{227}$

Recent empirical research by social psychologist Larry Heuer suggests why procedural justice might matter as much to members of socially marginalized groups as to others. ${ }^{228}$ Heuer's work indicates that the relationship between respectful treatment and perceived fairness is just as strong in transactions between members of different social groups as it is in transactions between members of the same social group. ${ }^{229}$ Based on this research, Heuer contends that:

[I]n encounters with out-group members, respect continues to matter because people are also motivated to believe that members of other groups value their groups. For example, in an encounter between two strangers-a young black male civilian and a middle-aged white police officer in New York City-it is likely that neither individual thinks of the other as a member of the same highly-valued social group. Regardless, the civilian may still be highly sensitive to whether the officer treats him with respect because respect communicates an

important role in the restorative justice movement. Restorative justice draws on the notion of voice and respect from procedural justice ...." (citations omitted)).

${ }_{227}$ See Barton Poulson, A Third Voice: A Review of Empirical Research on the Psychological Outcomes of Restorative Justice, 2003 UTAH L. REV. 167, 201 ("The data in this review were consistently favorable to restorative justice when compared to adjudication. If outcomes such as fairness, accountability, satisfaction, contrition and forgiveness, emotional well-being, and feelings of safety are important, then restorative justice is the clear choice."); see also Umbreit et al., supra note 111, at 284-89 (summarizing studies of recidivism rates among restorative justice participants). Although the results of some of the R.J. studies may be criticized because offenders self-selected themselves for participation, other studies have employed random assignment procedures and still reported favorable results. See Poulson, supra, at 169-70 (analyzing studies). It is notable, moreover, that R.J. participants, despite their enhanced perceptions of fairness, do not necessarily report greater satisfaction with outcomes, id. at 198 , which lends support to the view they are responding to procedural justice effects.

${ }^{228}$ See Heuer, supra note 11, at 221-25 (discussing how group standing affects belief of fairness).

${ }^{229} I d$. Some studies do, however, suggest that procedural justice effects are diminished among so-called "separatists"- that is, those "relatively rare" people "with a strong minority identification and a weak identification with American society ...." MacCoun, supra note 34, at 188 . 
important message about what the police officer thinks of the standing of the civilian's social group. ${ }^{230}$

In short, Heuer's analysis helps us to see that many of those who are marginalized by what we might view as "mainstream" society possess social identities that are important to them within other groups; the perceived status of these other groups may be implicated in their interactions with legal authorities.

3. Bargaining Is Just a Blip on the Radar Screen. For many defendants, plea negotiations represent but a brief moment in a lengthy involvement with the criminal justice system. Interactions with the prosecutor are followed not only by interactions with the judge, but also months, years, or even decades of incarceration, supervised release, or both. During this time, defendants may feel themselves in the power of corrections officers, probation officers, pardon and parole boards, appellate tribunals, and so forth. Treatment by such authorities over an extended period of time will be perceived as fair or unfair and may ultimately overcome any contrary impressions of the criminal justice system at the start of the process. Perhaps, in short, we would do better to focus our procedural justice efforts on prison officials and probation officers rather than on prosecutors. ${ }^{231}$

Although some defendants face a lengthy period of intensive involvement with the criminal justice system, many others do not. In misdemeanor and other low-level cases, the defendant is apt to receive a sentence of straight probation or a relatively brief period of closer supervision. In such cases, interactions with the prosecutor will loom particularly large as a source of information for the defendant about the fairness of the system as a whole. This suggests that plea bargaining reforms might do well to focus on lowstakes cases; in more serious cases, procedural justice benefits may

230 Heuer, supra note 11 , at 223.

231 Sumner Sydeman and his colleagues have offered a similar critique of 'Tyler's claim that procedural justice in civil commitment hearings will enhance therapeutic outcomes. See Sumner J. Sydeman et al., Procedural Justice in the Context of Civil Commitment: A Critique of Tyler's Analysis, 3 PSCYHOL. PUB. POL'Y \& L. 207, 215 (1997) ("crThe encounter of the respondent with legal authorities is quite limited in commitment hearings . . , and as such constitutes only a brief 'blip' in the overall treatment experience."). 
be overcome or rendered superfluous by good or bad treatment in prison.

On the other hand, there may also be real significance to procedural justice, even in serious cases. While acceptance of a conviction and sentence may enhance compliance with prison rules and the directives of corrections officers, ${ }^{232}$ contrary attitudes at the start of a prison term may lead to early disciplinary problems that establish a pattern of harshly adversarial interactions with corrections officers. Moreover, as noted in the previous section, heuristic theory predicts that earlier received information (procedural justice in plea bargaining) will have greater influence than later received information (procedural justice in prison). Once reached, fairness judgments, either positive or negative, may be difficult to reverse. ${ }^{233}$

4. The Empirical Studies Themselves Indicate a Surprising Degree of Satisfaction with Plea Bargaining. Much empirical research supports both the general hypothesis that procedural justice influences perceived legitimacy and the acceptance of legal rules and decisions, and the more specific hypothesis that procedural justice effects carry over into the criminal litigation context. $^{234}$ Unfortunately, there is much less empirical research available on plea bargaining in particular. There is no obvious reason, however, why the procedural justice dynamics would differ fundamentally in this context in comparison with, for example, a police officer's conduct during an arrest. ${ }^{235}$ Thus, one might be surprised to learn of one of the chief findings of some of the studies that have been conducted on plea bargaining: pleading guilty is associated with higher levels of perceived fairness among defendants than is going to trial. ${ }^{236}$ This finding poses a problem for the thesis that legitimacy and acceptance may be enhanced by

232 See supra notes 91-115 and accompanying text.

233 These timing considerations also underscore the need for police to attend to procedural justice, since an arrest by police officers is typically the very first step in the criminal process.

${ }^{234}$ See supra notes 35-39 and accompanying text.

235 See supra note 54 and accompanying text.

${ }^{236}$ See Casper et al., supra note 12 , at 499 ("[A] higher level of perceived procedural fairness is not associated with the trial setting . . .."); Landis \& Goodstein, supra note 225, at 702 (noting results "in line with Casper's finding that defendants who plea bargain are more likely than those who go to trial to perceive their 'treatment' as fair"). But see Heinz, supra note 225 , at 26 (finding that felony defendants preferred trials). 
aligning plea bargaining practices with the procedural justice model. After all, criminal trials are commonly viewed as the ne plus ultra of due process. If plea bargaining is perceived as no less procedurally fair than a trial, it might seem that either (a) plea bargaining practices already provide ample procedural justice, or (b) perceived fairness, at least in this context, is not significantly influenced all that much by procedural justice.

This reasoning, however, is based on a faulty premise. A criminal trial may be the ultimate of due process in the cramped way that the term is understood in legal doctrine, but that does not necessarily mean that a criminal trial actually embodies procedural justice in a meaningful way. Consider voice, often viewed as the core attribute of procedural justice. Alexandra Natapoff recently has catalogued the ways that criminal procedure "silences" defendants. ${ }^{237}$ In cases that go to trial, nearly half of defendants are dissuaded from testifying, largely because of the danger of perjury charges and sentence enhancements, and the possibility that evidence of criminal history will be introduced for impeachment purposes. ${ }^{238}$ Moreover, given the general structure of criminal liability, the testimony that is relevant and helpful to a defendant will be quite narrowly circumscribed in many cases, often excluding motive and mitigating circumstances that do not satisfy the technical requirements for an affirmative defense. ${ }^{239}$ Although defendants may place a high value on being able to express their views on such matters, they may be prevented from doing so on relevance grounds or discouraged from doing so by defense counsel's intent to develop a more legally advantageous, but less authentic, "story." 40 Lurking in the background of all this is the troubling reality of indigent criminal defense. Overburdened defense counsel simply may be incapable of ensuring that the defendant's perspective is adequately conveyed at trial. Of course, poor legal representation is a structural problem that infects not only trials, but also guilty pleas. At the same time, given the idealized role of

\footnotetext{
237 Alexandra Natapoff, Speechless: The Silencing of Criminal Defendants, 80 N.Y.U. L. REV. 1449 (2005).

${ }^{238}$ Id. at $1459-60$.

239 See id. at 1469-70 ("[D]efendant motive, jury sympathy, and mitigating circumstances that do not rise to the level of technical defenses are irrelevant.").

${ }^{240}$ Id. at 1470 .
} 
trials in the popular imagination, it would not be surprising if there were heightened expectations for meaningful voice at trial and if counsel's failure to provide voice rankled more in the trial setting than elsewhere. ${ }^{241}$ In short, we ought not take much comfort in findings that plea bargaining is perceived to be more procedurally fair than going to trial; there are good reasons to suspect that trials systematically fall far short of defendant expectations from a procedural justice standpoint. ${ }^{242}$

Additionally, we should note that the case disposition findings emerge from studies conducted in particular times and places. The data was drawn from the $1970 \mathrm{~s}$ and early $1980 \mathrm{~s},{ }^{243}$ before the explosion of get-tough sentencing laws that greatly enhanced prosecutorial plea-bargaining leverage. ${ }^{244}$ As the prosecutor's ability to effectively dictate the terms of the plea deal has increased, it would not be surprising to learn that defendant perceptions of procedural fairness have diminished. Moreover, the studies that covered particular jurisdictions, ${ }^{245}$ did not detail the plea bargaining practices in those jurisdictions. ${ }^{246}$ It may be that the prevuiling practices in those jurisdictions were relatively strong from i procedural justice standpoint. If so, satisfaction with proceduros in those jurisdictions would not necessarily indicate satisfindiont elsewhere.

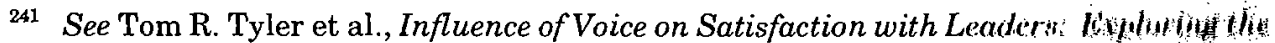

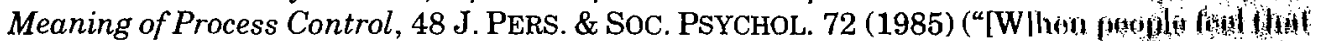
their opportunity to speak is a 'sham,' rather than an honest opportunity lo bifitimes 1 ligs decision, they may react ... . with anger.").

242 Landis and Goodstein relate their case disposition findings to dofondiant poffrowitas

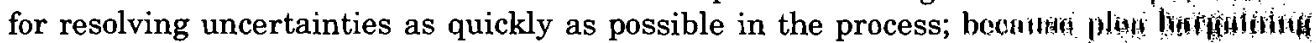
resolves uncertainties more quickly than trial, defendants percoive hin iulunims of

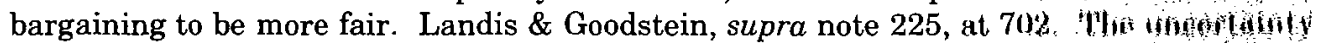

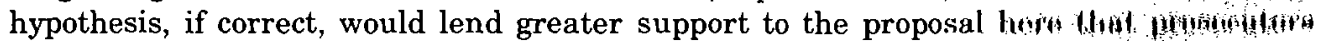

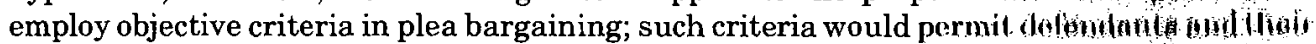

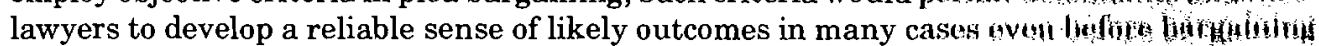
begins.

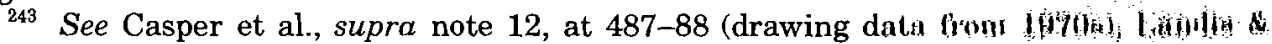
Goodstein, supra note 225, at 685 (drawing data from early $1980 \mathrm{~s}$ ).

244 O'Hear, supra note 5, at 888.

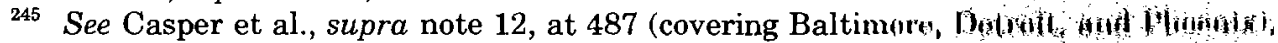
Landis \& Goodstein, supra note 225, at 685 (covering Illinois and Minuobitia).

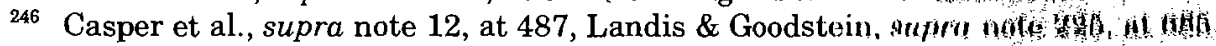




\section{CONCLUSION}

In a system dominated by plea bargaining, criminal justice has become more a matter of administrative than of judicial adjudication. As Gerard Lynch has argued, this transformation is neither intrinsically good nor bad. ${ }^{247}$ Rather, the question is whether, given a range of different ways of structuring administrative adjudication, decisions are being made in a manner that effectively advances the underlying goals of the criminal justice system. Doing so undoubtedly requires accuracy in separating the guilty from the innocent and in separating those deserving of heavy punishment from those deserving of light punishment. Yet an exclusive focus on the outcomes of plea bargaining misses the important contributions that process potentially makes to the acceptance of outcomes and ultimately makes to attitudes about the legitimacy of the criminal justice system. Procedural justice in plea bargaining thus warrants considerably more attention than it has received from scholars and practitioners.

Drawing on a large body of procedural justice research, I have proposed five process norms for plea bargaining: (1) defendant voice, (2) use of objective criteria in making and responding to plea offers, (3) explanation of plea bargaining positions, (4) consideration of defendant arguments, and (5) avoidance of high-pressure tactics that show disrespect for defendants' legal rights. The specifics of how these norms are best implemented will vary by jurisdiction, depending on such factors as case volume, resources available to law enforcement and court personnel, offender demographics, and local rules and customs of criminal procedure. In some jurisdictions, robust procedural justice norms can be implemented with little or no disruption of existing practices; in such locales, there seems no good reason for prosecutors not to incorporate the norms into office policies and practices. In other jurisdictions, particularly those where the total amount of time that judges and lawyers spend on most cases is better measured in minutes than hours, implementing

${ }^{247}$ See Lynch, supra note 4, at 2145 ("An understanding of the different functions of the administrative and judicial aspects of our current system, moreover, should help us to identify areas in need of change-and areas where change is not needed."). This position also seems consistent with emerging scholarly consensus. See supra notes 4-5 and accompanying text. 
procedural justice may be considerably more challenging. It is in such settings that we are most likely to see real trade-offs between procedural and distributive justice.

The prospect of such trade-offs doubtlessly explains much of the traditional disregard for procedural justice in plea bargaining. I have attempted to show, however, that the significance of these trade-offs may be less than is commonly assumed. Procedural justice can be meaningfully delivered through processes that are well short of trial-type adjudication. Moreover, procedural justice need not necessarily undercut, but may actually make important contributions to, distributive justice. Additionally, given what seems to be a substantial degree of indeterminacy in the content of distributive justice, any claims as to distributive justice costs must be advanced with some modesty. Finally, whatever the costs may be, they should be assessed relative to the expected benefits of increased acceptance and perceived legitimacy among defendants-including greater cooperativeness with legal authorities and reduced risks of recidivism-as well as the benefits of enhanced transparency to system outsiders.

Certainly the assessment of many of the costs and benefits of procedural justice in plea bargaining remains largely at the level of hypothesis and requires considerably more real-world experimentation and empirical research. There are compelling reasons to believe, however, that thoughtful efforts to integrate procedural justice norms into plea bargaining will not only help the system do a better job of giving defendants the sort of fair treatment that they want and deserve, but also will advance important public interests in efficient and transparent crime control. 